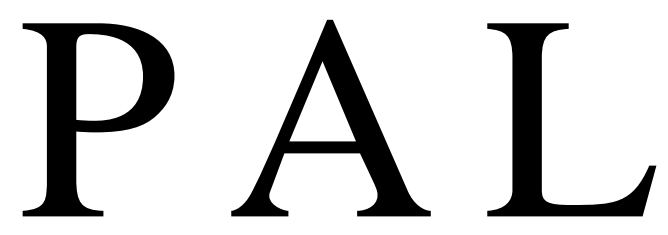

REVIEW

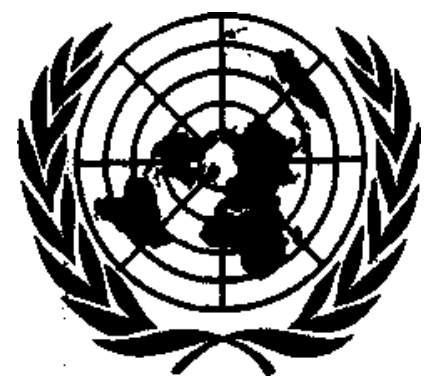

UNITED NATIONS 


\section{CEPAL Review}

Executive Secretary

Norberto González

Deputy Executive Secretary for Economic and Social Development Gert Rosenthal

Deputy Executive Secretary for Co-operation and Support Services Robert T. Brown

Director of the Review

Raúl Prebisch

Technical Secretary

Adolfo Gurrieri

Deputy Secretary

Rosa Nielsen

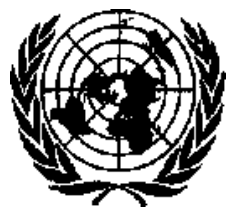

UNITED NATIONS

ECONOMIC COMMISSION FOR LATIN AMERICA AND THE CARIBBEAN

SANTIAGO, CHILE, APRIL 1986 


\section{E P A L}

Review

Santiago, Chile

Number 28

\section{CONTENTS}

Address delivered by the Executive Secretary of ECLAC, Mr. Norberto González, when opening the Meeting on Growth, Adjustment and the Debt in Latin America.

Central America: Bases for a reactivation and development policy. ECLAC Mexico Subregional Headquarters

Thoughts on industrialization, linkage and growth. Joint ECLAC/UNIDO Industrial Development Division

Inflation and stabilization policies. Daniel Heymann

Transnational corporations in Argentina, 1976-1983. Daniel Aspiazu, Eduardo Basualdo and Bernardo Kosacoff

Social security and development in Latin America. Carmelo Mesa-Lago

Changes of social relevance in the transplantation of theories: the examples of economics and agronomics. Ivo Dubiel

The preparation of natural and cultural heritage inventories and accounts. Nicolo Gligo

Co-operativism and popular participation: new considerations regarding an old subject. Roberto P. Guimarães

Notes on trade from the standpoint of the periphery. Raúl Prebisch 


\section{Central America: Bases for a reactivation and development policy*}

\author{
ECLAC Mexico \\ Subregional \\ Headquarters
}

Since the beginning of the present decade, and not withstanding a slight revival recorded in the majority of countries in 1984, Central America has been sunk in the deepest economic depression and shaken by the most serious political upheavals of the last half-century. The climate of instability and confusion which is prevailing seriously hampers the search for solutions to political as well as social and economic problems, yet the search for such solutions is the greatest challenge facing Central Americans today, and one which cannot be put off any longer.

This search should be begun by examining the outstanding features of the evolution which has taken place in the Central American economies and societies since the war and finding out why these features underwent so sharp a change towards the end of the 1970s. This analysis is presented in chapters 1 and II. Chapter HI makes some observations on the short-term prospects for the region's economies, while finally chapter IV sets out a number of proposals designed to form the basis for a policy of regional reactivation and development.

With regard to the latter aspect, the resources available in the region are identified and the role which intra-regional co-operation could play in bringing a process of reactivation and development into being is specified, the interaction between the economic and social spheres and the political sphere is investigated, and finally some observations are made on the the role of the State.

-This article was prepared as part of the basic documentation for the Expert Meeting on Crisis and Development in Latin America and the Caribbean (Santiago, Chile, 29 April-3 May 1985), organized by the Secretariat of BCAC

\section{Main features of the style of development in Central America since the war $^{1}$}

The origin, scope and possible consequences of the crisis cannot be understood without analysing the main features of the evolution of the economies and societies of Central America since the war. The first aspect which strikes one is the dynamic growth achieved over a thirtyyear period - naturally with differences from one country to another- within an atmosphere of financial and monetary stability. A second striking aspect is the decisive influence of external factors, which have been essential determinants not only of economic behaviour, but also of the mutual influence of many political factors. Here $\mathrm{He}$ the historical roots of the repeated propensity of Central Americans to seek abroad the explanations and solutions for the problems affecting them. Furthermore, the fragmentation of Central America since the short-lived federation broke up has also contributed to the fact that each of the countries has resigned itself historically to having a scanty margin of action with regard to its own fate, due to the preponderance of factors beyond its control.

A third noteworthy feature is that, in the thirty years since the end of the Second World War, most of the considerable changes undergone by the economies of the region have been simply superimposed on the economic and social structure that already existed, without bringing about any essential changes in it: a process referred to in the present study as "superimposed development".

Finally, the fruits of the long period of economic expansion which took place after the war were distributed in a flagrantly inequitable

'Sections I and II of this paper are updated versions of part of the text of ECLAC (1983a). 
manner between the different strata of the population, within the framework of a concentrative (or at least exclusive) process, thus preventing any significant relief of the extreme poverty which persists in the region.

\section{Economic growth}

The first feature of the development of the Central American countries during the last three decades was undoubtedly its sustained dynamism. The gross domestic product of the subregion as a whole grew at the rate of $5.3 \%$ per year in real terms between 1950 and 1978, although of course there were differences of, degree between the various countries, with the highest rates corresponding to Nicaragua and Costa Rica and the lowest to Honduras. As a result, the per capita real income practically doubled during this period. Even between 1970 and 1978, when the subregion had to face particularly severe problems - the rise in hydrocarbon prices, imbalances in the international monetary and financial field, shortages of raw materials and of some foodstuffs in 1974-1975, various droughts and three large-scale natural disasters- the real average growth rate exceeded $5.6 \%$ per year.

Some other features of this growth may also be noted. First of all, during the 28 years in

Table 1

CENTRAL AMERICA: GROWTH RATE OF GROSS DOMESTIC PRODUCT"

(Percentages)

\begin{tabular}{lccccc}
\hline & Costa Rica & El Salvador & Guatemala & Honduras & Nicaragua \\
\cline { 2 - 6 } Average annual rates & & & & & \\
$1950-1960$ & 6.4 & 4.8 & 3.7 & 2.8 & 5.4 \\
$1960-1970$ & 5.9 & 5.5 & 5.2 & 5.0 & 6.5 \\
$1970-1978$ & 6.3 & 5.4 & 6.0 & 4.7 & 3.9 \\
$1978-1983$ & -0.4 & -4.6 & 0.8 & 1.7 & -2.0 \\
Annual rates & & & & & \\
1970 & 7.2 & 3.4 & 5.5 & 3.5 & -0.2 \\
1971 & 6.8 & 4.9 & 5.5 & 5.8 & 3.4 \\
1972 & 8.2 & 5.4 & 7.5 & 4.4 & 2.8 \\
1973 & 7.5 & 4.7 & 6.6 & 5.8 & 5.3 \\
1974 & 5.4 & 6.7 & 6.1 & -0.3 & 13.5 \\
1975 & 2.2 & 5.8 & 2.4 & -3.1 & 1.5 \\
1976 & 5.5 & 3.1 & 7.6 & 6.5 & 5.8 \\
1977 & 8.5 & 6.1 & 7.4 & 9.6 & 6.1 \\
1978 & 6.2 & 6.8 & 4.9 & 9.3 & -5.9 \\
1979 & 5.3 & -1.2 & 4.7 & 6.0 & -24.5 \\
1980 & 0.9 & -8.1 & 3.8 & 3.3 & 8.3 \\
1981 & -2.3 & -7.9 & 1.1 & 0.6 & 5.4 \\
1982 & -7.1 & -5.2 & -3.3 & -0.2 & -0.6 \\
1983 & 2.3 & -0.1 & -2.0 & -1.1 & 5.2 \\
\m & 5.0 & 1.5 & 0.2 & 2.8 & -1.5 \\
\hline
\end{tabular}

Source: ECLAC, on the basis of official data.

"At constant 1970 prices.

Preliminary figures. 
question negative growth rates were recorded on only a very few occasions, almost always associated with some natural disaster (twice in Honduras and once in Nicaragua and Costa Rica). Secondly, while there were frequent - almost annual- cyclical fluctuations, these took place against an overall background of notably stable growth. Cyclical drops were only brief, and only exceptionally did the product fall for two years running in any of the countries. Finally, the cyclical evolution of the gross domestic product of the five countries showed great similarity, reflecting both their common form of insertion in the international economy and the high degree of economic interdependence achieved through the integration agreements of the 1950s and 1960s (see table 1 and figure I).

The most dynamic sector was generally manufacturing, propelled by the expanded market and the industrial development policies created as part of the integration process. As a result, the degree of industrialization of the subregion rose from $12.3 \%$ in $\mathrm{I} 960$ to $16.8 \%$ in 1978.

\section{The decisive influence of the external sector}

The sustained manner $¡ n$ which the Central American economies grew largely reflected the long boom in the international economy which followed the Second World War. During that period, the industrialized countries grew at a cumulative annual rate of $5.0 \%$, while the volume of world trade expanded at the rate of $9.0 \%$. Albeit in different degrees, all the countries of the region managed to take advantage of the situation: the value of their exports of goods and services to the countries outside the subregion increased by a factor of thirteen between 1950 and 1978, rising from US\$ 250 million to US\$ 3-2 billion, while the export sector diversified significantly, both as regards the composition of its products and their geographical destination. ${ }^{2}$ The boom in the

'For the region as a whole, the main export product of each country in 1950 contributed $70 \%$ of total foreign exchange income from exports of goods. This percentage declined by almost half by traditional export sector also created sufficiently easy conditions to facilitate the bold decision to adopt mutual free trade in virtually all products originating from the subregion within a space of not more than five years. This was responsible for the intensive industrialization process which eventually became a second source of growth, although this never ceased to depend ultimately on the evolution of the traditional external sector. The comfortable economic situation referred to, together with the' intensive process of modernization in the subregion, also helped to create consumption patterns in certain strata of the population which imitated those of more advanced societies and accentuated demand for imported goods.

During the 1960s and 1970s, the external sector of the Central American countries underwent significant changes. The relative importance of foreign trade tended to grow - the export and import coefficients for the subregion as a whole rose from $18.6 \%$ and $16.3 \%$ respectively in 1950 to $30.4 \%$ and $33.6 \%$ in $1978 ;^{3}$ the structure of exports and imports changed radically - the former included a growing proportion of non-traditional articles, while within the latter the proportion of intermediate and capital goods increased; intraCentral American trade grew rapidly until it accounted for a high and growing portion of the total exports of each of the countries, while at the same time also accounting for an increasingly high proportion of their total imports; and movements on the capital account became more and more important as the gap on current transactions tended to widen and new sources of international financing, both public and private, became available. As a result, the

mid-1970 (36.1\%), chanks to the diversification of the export sector, although it rose again to $45 \%$ in 1978 as a result of the high prices of coffee which predominated that year, since the weight of this commodity in the total value of exports is high. Furthermore, in $195080 \%$ of Central America's external trade was with a single country (the United States of America), but this percentage declined to $35 \%$ in 1978 .

If reciprocal trade is excluded from these figures, the export coefficient for the region as a whole evolved from $18.5 \%$ in 1950 to $16.7 \%$ in $\mathrm{I} 960$ and $23.5 \%$ in 1978 ; the coefficients of extraregional imports in these same years were $16.2 \%, 19.8 \%$ and $27.3 \%$, respectively. 
Figure I

CENTRAL AMERICA: GROSS DOMESTIC PRODUCT AT MARKET PRICES

(Annual growth rates)

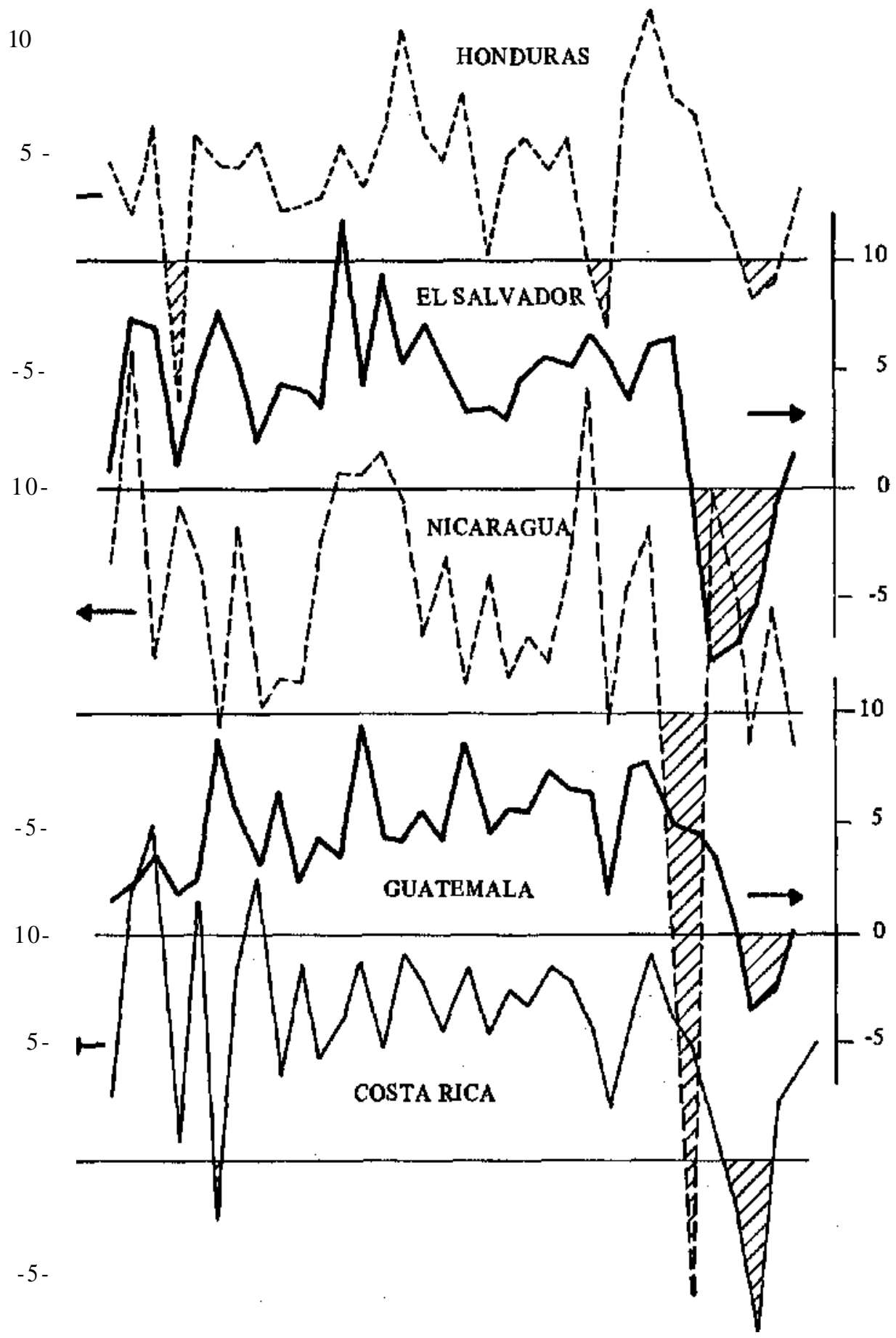

$\begin{array}{llllllll}1950 & 1955 & 1960 & 1965 & 1970 & 1975 & 1980 & 1985\end{array}$


servicing of the external debt began to absorb an increasingly large proportion of the foreign exchange generated by exports of goods and services.

Even so, throughout this period of growth, diversification and change in the external relations of the region, the eseential features of those small agricultural export economies persisted: the evolution of the external sector largely explained the global economic behaviour of the economy, while the restrictions originating in that sector set the limits on the rate of domestic economic activity. A direct relationship is thus observed between the level of exports on the one hand and the rates of economic expansion, capital accumulation, investment, procurement of fiscal revenue, level of employment and import capacity on the other.

External financing acted as a shock absorber during periods of contraction, preventing drops in the value of exports from being reflected automatically in a restriction on the capacity to import (and hence on the growth capacity of the economy), and at the same time it facilitated the process of "superimposed development" referred to below. When weakening of external demand coincided with restrictions on the flow of external financing (which served at least partly to make up for the drop in exports), however, the restrictions originating in the external sector had the effect of slowing economic growth and even bringing about a contraction in economic activity in real terms.

The influence of external factors on events in the countries of the subregion was not limited to the economic sphere. Some of the consequences of Central America's dependence on exports profoundly affected the shaping of its societies and the political order prevailing in them. It is well known, for example, that the cultivation of one or two basic export products had a decisive influence in fixing the division of labour, because of the intensive and seasonal nature of labour requirements for such crops. The availability of labour has thus played a vital role in the economic development of the region as well as in defining the dual and interdependent nature of export and subsistence agriculture, and these facts largely explain, in turn, the inequitable income distribution structures.

The organization of the Central American economies around one or two export products profoundly influenced also the "patterns of authority": the symbiotic relation between the dominant economic groups (agricultural exporters and traders) and governments, the legacy of corruption from colonial times, and the repressive methods used historically to ensure the availability of labour have helped to consolidate the authoritarian and nonparticipative systems characteristic of the period since the war, which have taken different forms from one country to another, or within a single country at different times (the main exception being Costa Rica).

Furthermore, factors of external origin have also decisively influenced the political interaction in the countries of the subregion. The virtual hegemony exerted by the United States since the signing of the Clayton-Bulwer treaty in 1850 has found a new expression in the period since the war because of the latent conflict existing between the two main superpowers of the world. This is not the place to go into detail about the role of United States foreign policy in Central America - a topic which has been the subject of many studies in recent years-, but it is worth stressing the considerable influence which the United States has achieved in the region. It is not a question, of course, of claiming that the United States has an omnipotent role or of insinuating that Central American events depend largely on the designs of one or other of the superpowers, since the interaction between the national political actors has its own dynamics, but it may nevertheless be maintained that the United States has shown a capacity for fixing the limits of political interaction in the countries of the region by putting its weight on the side of the national actors whose position is closest to the objectives of its own foreign policy.

The preferences of United States policy have not always formed a coherent set of objectives: some administrations have been mainly concerned with security -above all the "containment of communism" - while others have been more interested in gradual orderly change towards more pluralistic and equitable 
societies. In this respect, United States governments have sometimes supported national actors who advocate orderly and peaceful changes, within the framework of a foreign policy vis-a-vis the Latin American countries which some authors have called "idealistic". This happened, for example when the United States favoured the heterogenous alliances which overthrew dictatorships in Guatemala, El Salvador and Honduras in the period following the war, or the governments which promoted changes under the "Alliance for Progress" in the 1960s, as well as the possibly somewhat reluctant support given to the similarly heterogenous alliance which took power in Nicaragua in 1979. On other occasions, the United States Government has preferred to help national actors who, in its opinion, have the best qualifications for ensuring a minimum of stability in the face of radical challenges to the status quo. The best example of this more "realistic" policy might perhaps be the support given by the United States Administration to the forces which overthrew the elected government in Guatemala in $1954{ }^{4}$

At all events, when contradictions have arisen in United States foreign policy -as happens fairly often - between the objective of

"It has to be acknowledged that the swing from "realism" to "idealism" in United States foreign policy is a simplified description. Nevertheless, it is based on deep analyses such as the description provided by Dexer Perkins (1962, pp. 136-155) of cycles of "quietism" and "activism". On other occasions it is based on what Stanley Hoffmann (1968, pp. 177 and 178) describes as "dualism" in the United States approach to foreign policy, one of whose expressions involves speaking two distinct languages, neither of which is completely convincing and which are hard to reconcile. The first of these is the language of power, the second that of shared interest and harmony. Hoffmann himself observes rather more graphically that only a symbolic eagle is capable of easily holding both arrows and an olive branch at the same time. Finally, the realism alternation between "realism" and "idealism" in foreign policy also finds support in the recent description made by Huntington (1981, pp. 3, 42, 64 and 68) of the United States political system, one of whose essential features is the distance between political ideals and political reality. Huntington acknowledges that this "distance" exists in all societies but asserts that the United States is special in the way it deals with the problem, namely, through four different responses which nonetheless form part of a "cyclic pattern" beginning with "moralism", which seeks to eliminate it; then falls into "cynicism", through which it tolerates it, moves on to "complacency", which seeks to ignore it, and ends with "hypocrisy", in which it denies the existence of such a problem and thus returns to the beginning once again with "moralism". promoting orderly change and that of avoiding threats to security, the United States Government has invariably preferred to support those actors in each country which it has considered most capable of defending its own interests. It is in this way that the various Administrations of that country have managed to fix the geopolitical limits referred to earlier.

\section{3- Superimposed development}

The economies and societies of the Central American countries are very different from what they were 30 years ago, not only in quantitative aspects - the gross domestic product rose from US\$ 1.95 billion to US\$7.52 billion (at 1970 prices) between 1950 and 1980, while over the same period the population rose from eight million to over twenty million inhabitants- but also because important qualitative changes have taken place. The societies are much more segmented and pluralistic, a noteworthy feature being the appearance of middle-income strata attributable partly to the progressive urbanization (only $16 \%$ of the population lived in urban areas in 1950, compared with $43 \%$ in 1980); the importance of secondary sector activities in the economies has increased (their relative participation rose from $14.6 \%$ to $24.1 \%$ between the two periods in question), and in general the system of production has been modernized and diversified year by year. The different geographical regions of the countries are now much better integrated, thanks to heavy investments made in the physical transport and communications infrastructure, and advances have also been made in the provision of education and especially health services. These changes are to be attributed essentially to the "spillover" caused by the style of development which has prevailed in all of the countries -albeit with specific characteristics from one to another- over the whole period under analysis. It may be considered that these changes have generally speaking been the only ones permitted by those who have had the possibility of keeping changes within certain limits, outstanding among these actors being those who obtain their economic power from the agricultural export pattern which is so vital for this type of historical 
development in the region. Consequently, it may be seen that the considerable changes which have taken place in the three decades since the war are characterized essentially by the way in which the new economic and social strata have simply been juxtaposed with the existing ones, within a process of change and modernization which has not threatened in essence the existing economic structure.

The foregoing is simply another way of explaining a process of gradual peaceful change: as long as the pre-existing structures are not eliminated, then all the changes which take place in patterns of development must, by definition, be of an additive or superimposed nature, although this does not mean that they should necessarily be scorned for this reason.

What it is desired to stress here, however, is that when these changes have seriously threatened the existing structures and vested interests, they have almost invariably encountered their limit, above all when the interests of the dominant groups have been identical —as has frequently, but not always, occurred - with those of the main international actor in the Central American political arena in the terms already referred to in previous paragraphs. Thus, peaceful and orderly changes or reforms have had to comply with very tight limits in most of the countries of the region. To put this another way, economic progress has led to substantial social change, with many groups rising in the income scale and the formation of middle classes, but the maintenance of this historical pattern of development has meant that there has been only a slow and halting advance by the political institutions.

This essential characteristic of "superimposed development" has frequently obliged governments to seek substitutes for changes which perhaps run the risk of exceeding these limits. Thus, for example, recourse was had to external financing partly in order to postpone or take the place of increases in the tax base; State land was distributed in programmes called "colonization" instead of reorganizing land tenure systems, and external saving was used as a substitute (instead of a complement) to the inadequate machinery for tapping national saving.

By the same token, the tax burden came to be an interesting indicator of the limits which "superimposed development" had to face in Central America. Although important changes took place within the taxation system in all the countries -as a reflection of the changes which were taking place within the system of production - it is curious that the amount of fiscal resources procured, as a percentage of the gross domestic product, remained constant in some countries or only grew very slowly in other (see table 2). Furthermore, this coefficient of taxation was extremely low compared with that of other countries of similar economic and social structure, and this circumstance should not be considered a mere accident: organized business

Table 2

CENTRAL AMERICA: TAX COEFFICIENT

\begin{tabular}{lrrrrrrrrrr}
\hline & 1955 & 1960 & 1965 & 1970 & 1975 & 1980 & 1981 & 1982 & 1983 & $1984^{\circ}$ \\
\cline { 2 - 9 } Central America & 9.5 & 9.3 & 9.4 & 9.7 & 11.3 & 11.4 & 10.9 & 9.2 & 11.5 & 12.7 \\
Costa Rica & 10.1 & 10.0 & 11.8 & 12.1 & 12.7 & 11.4 & 11.8 & 12.9 & 15.7 & 17.0 \\
El Salvador & 10.8 & 10.9 & 9.9 & 10.3 & 12.0 & 11.1 & 11.3 & 10.7 & 11.1 & 11.7 \\
Guatemala & 8.5 & 7.8 & 7.6 & 7.8 & 9.5 & 8.6 & 7.5 & 7.2 & 6.3 & 5.3 \\
Honduras & 7.3 & 10.1 & 9.7 & 11.2 & 12.1 & 14.0 & 13.2 & 12.8 & 12.0 & 13.8 \\
Nicaragua & 10.8 & 9.4 & 10.2 & 9.4 & 10.6 & 18.4 & 18.5 & 20.7 & 25.0 & 31.5 \\
\hline
\end{tabular}

Source: ECLAC, on the basis of official data.

"Preliminary figures. 
Table 3

\section{CENTRAL AMERICA: COEFFICIENT OF TOTAL CENTRAL GOVERNMENT EXPENDITURE}

\begin{tabular}{lrrrrrrrrrr}
\hline & 1955 & 1960 & 1965 & 1970 & 1975 & 1980 & 1981 & 1982 & 1983 & $1984 "$ \\
\cline { 2 - 10 } Central America & $\mathbf{1 0 . 6}$ & 11.2 & $\mathbf{1 1 . 3}$ & $\mathbf{1 1 . 6}$ & $\mathbf{1 5 . 8}$ & 19.3 & 20.2 & 20.4 & 23.3 & 22.7 \\
Costa Rica & 11.2 & 13.3 & 13.8 & 13.7 & 17.9 & 20.0 & 16.9 & 16.8 & 21.9 & 21.8 \\
El Salvador & 10.9 & 12.2 & 10.9 & 10.3 & 13.4 & 17.2 & 19.8 & 20.5 & 28.0 & 22.1 \\
Guatemala & 9.5 & 9.3 & 10.6 & 9.9 & 12.5 & 15.2 & 16.9 & 14.4 & 12.1 & 11.2 \\
Honduras & 10.0 & 12.2 & 10.8 & 14.7 & 21.0 & 24.9 & 24.1 & 28.1 & 26.2 & 29.7 \\
Nicaragua & 12.4 & 11.1 & 11.2 & 11.8 & 19.4 & 29.5 & 32.4 & 37.4 & 56.4 & 55.1 \\
\hline
\end{tabular}

Source: ECLAC, on the basis of official data.

"Preliminary figures.

circles in all the countries - albeit to different degrees - stubbornly resisted rises in levels of taxation, especially taxation on production and income. The financial restrictions due to the smaller procurement of fiscal revenue severely limited the capacity of the public sector to play a more active role in development, while the modest increases achieved in the coefficient of public expenditure (see table 3) were increasingly financed through greater indebtedness, especially of external origin.

The limited participation of the public sector in the gross domestic product, as measured through the procurement of tax revenue and central government expenditure, also fitted in with the "anti-dirigisme" position of the dominant groups in Central American societies. In the 1950s and 1960s, the public sector was gradually taking control of such public services as the generation and distribution of electricity, telephone communications, rail transport and the management of ports, while State activity was also strengthened with the establishment of public development banks and institutions for regulating the prices of commodities. In all countries, however, the public sector scrupulously avoided participating in activities of interest to private enterprise, the main exception to this rule being the Costa Rican financial intermediation system.

Another example of the persistence of prior structures in these processes of change was the low level of backward or forward integration of traditional agricultural export activities, in the sense that the sectors depending on these have not tried to diversify systematically in order to invest in more complex activities. The new agricultural export activities (cotton, sugar and beef) were thus limited to repeating the pattern of traditional commodities, with their scanty linkages with other productive activities. In other words, the traditional producers diversified very little, and the State shared only slightly in the surplus generated by them. It will thus readily be understood how the traditional economic and social structures persisted and the changes mentioned were simply superimposed on them without succeeding in altering them in essence. In other words, the changes occurred only within relatively narrow limits (although these varied somewhat from country to country). Thus, despite the considerable expansion and change which took place in the Central American economies and societies in the 30 years following the war, that change was, paradoxically, not sufficient to meet the growing expectations of numerous sectors of the population. Furthermore, the instinctive desire to preserve vulnerable social systems led to the maintenance in most of the countries of the existing economic patterns - which were able to take advantage of the boom in the international economy- based on political institutions that were of an exclusive nature, at least as regards 
the distribution of power and of the fruits of economic development. Consequently, the social mobilization and mobility which accompanied the postwar boom were not able to offset the backwardness of some political structures.

\section{The exclusive nature of development}

As a result of this, despite their economic dynamism the countries of the subregion were not capable, during the 30 years after the war, of significantly improving income distribution or of reducing the number of Central Americans living in a state of extreme poverty. According to household surveys carried out in recent years, towards 1980 for example the poorest $20 \%$ of the population shared less than $4 \%$ of the national income, while at the other extreme the richest $20 \%$ of the population shared more than $55 \%$. There were considerable differences from one country to another, the most untypical features corresponding once again to Costa Rica (see table 4). In countries where surveys were carried out at different times, although the methodologies used were not always comparable the available evidence indicates that the gap between the groups at the two extremes of the scale widened, even though the relative share of the intermediate strata may have tended to increase (see table 5). In the case of Guatemala and Costa Rica, the per capita real income of the poorest $20 \%$ of the population actually went down. In addition, as is pointed out below, there is evidence that further deterioration occurred in the distributive structure between 1980 and 1984, as a result of increasing levels of unemployment and declines in the value of real wages.

In absolute figures, out of a total of over 20 million Central Americans in 1980, some 13.2 million $(64 \%)$ were living in a state of poverty -in the sense that their income did not cover their basic needs- while over 8.5 million $(41 \%)$ did not even have sufficient income to cover the value of the minimum shopping basket of food considered necessary in order to meet their biological nutritional needs (see tableó). The situation was much more serious in rural areas than in urban ones, though there were considerable differences from one country to another (in Costa Rica, less than $25 \%$ of the population lived in poverty, whereas in Guatemala the proportion was over $70 \%$ ). Moreover, although it is very likely that the percentage of Central Americans living a state of poverty nowadays is less than it was 30 years ago, it is nevertheless true that in absolute terms, because of population expansion, there are now more poor people (and also more people who

Table 4

\section{CENTRAL AMERICA: STRUCTURE OF INCOME DISTRIBUTION AND LEVELS OF PER CAPITA INCOME, BY COUNTRIES, TOWARDS 1980}

(1970 dollars)

\begin{tabular}{|c|c|c|c|c|c|c|c|c|c|c|}
\hline \multirow[b]{2}{*}{ Strata } & \multicolumn{2}{|c|}{ Costa Rica } & \multicolumn{2}{|c|}{ El Salvador } & \multicolumn{2}{|c|}{ Guatemala } & \multicolumn{2}{|c|}{ Honduras } & \multicolumn{2}{|c|}{ Nk:aragua } \\
\hline & $\begin{array}{c}\text { Per- } \\
\text { cent- } \\
\text { age }\end{array}$ & $\begin{array}{l}\text { Aver- } \\
\text { age } \\
\text { income }\end{array}$ & $\begin{array}{c}\text { Per- } \\
\text { cent- } \\
\text { age }\end{array}$ & $\begin{array}{c}\text { Aver- } \\
\text { age } \\
\text { income }\end{array}$ & $\begin{array}{c}\text { Per- } \\
\text { cent- } \\
\text { age }\end{array}$ & $\begin{array}{l}\text { Aver- } \\
\text { age } \\
\text { income }\end{array}$ & $\begin{array}{l}\text { Per- } \\
\text { cent- } \\
\text { age }\end{array}$ & $\begin{array}{c}\text { Aver- } \\
\text { age } \\
\text { income }\end{array}$ & $\begin{array}{c}\text { Per- } \\
\text { cent- } \\
\text { age }\end{array}$ & $\begin{array}{l}\text { Aver- } \\
\text { age } \\
\text { income }\end{array}$ \\
\hline Poorest $20 \%$ & 4.0 & 176.7 & 2.0 & 46.5 & 5.3 & 111.0 & 4.3 & 80.7 & 3.0 & 61.9 \\
\hline $30 \%$ below the mean & 17.0 & 500.8 & 10.0 & 155.1 & 14.5 & 202.7 & 12.7 & 140.0 & 13.0 & 178.2 \\
\hline $30 \%$ above the mean & 30.0 & 883.0 & 22.0 & 341.2 & 26.1 & 364.3 & 23.7 & 254.6 & 26.0 & 350.2 \\
\hline Richest $20 \%$ & 49.0 & 1165.2 & 66.0 & 1535.5 & 54.1 & 1133.6 & 59.3 & 796.3 & 58.0 & 1199.8 \\
\hline
\end{tabular}

Source: ECLAC, on the basis of official data provided by countries. 
Table 5

\section{CENTRAL AMERICA: EVOLUTION OF FAMILY INCOME DISTRIBUTION DURING THE 1970s}

(1970 dollars)

\begin{tabular}{|c|c|c|c|c|c|c|c|c|c|}
\hline \multirow[b]{2}{*}{ Strata } & \multicolumn{4}{|c|}{ Guatemala $^{0}$} & \multicolumn{2}{|c|}{ Costa Riica } & \multicolumn{3}{|c|}{ Honduras } \\
\hline & 1970 & 1980 & $\begin{array}{c}\text { Growth } \\
\text { rates } \\
\text { (annual } \\
\text { average) }\end{array}$ & 1971 & 1977 & $\begin{array}{c}\text { Growth } \\
\text { rates } \\
\text { (annual } \\
\text { average) }\end{array}$ & 1968 & 1979 & $\begin{array}{c}\text { Growth } \\
\text { rates } \\
\text { (annual } \\
\text { average) }\end{array}$ \\
\hline Poorest $20 \%$ & 1088 & 996 & -0.9 & 572 & 528 & -1.4 & 85 & 287 & 6.4 \\
\hline $\begin{array}{l}30 \% \text { below the } \\
\text { mean }\end{array}$ & 2014 & 1962 & -0.3 & 1167 & 1495 & 3.7 & 206 & 564 & $5-8$ \\
\hline $\begin{array}{l}30 \% \text { above the } \\
\text { mean }\end{array}$ & 3702 & 3865 & 0.4 & 2269 & 2639 & 2.3 & 522 & $1055^{\prime}$ & 4.6 \\
\hline Richest $20 \%$ & 9098 & 12393 & 3.1 & 5756 & 6465 & 1.8 & 2476 & 3958 & 3.4 \\
\hline Richest $10 \%$ & 12081 & 12970 & 4.0 & 7874 & 8737 & 0.9 & 3649 & 11395 & 6.2 \\
\hline Average income & 3752 & 4426 & 1.7 & 2297 & 2639 & 1.3 & 731 & 1338 & 4.1 \\
\hline
\end{tabular}

Source: ECLAC, on the basis of official data provided by countries.

" Urban sector.

are not poor) than in the period immediately after the Second World War.

In short, the characteristic style of development of the region has been concentrative, or at any rate of an exclusive nature in the sense that it has favoured the different strata of the population in a flagrantly inequitable manner, accentuating the degree of income concentration in some countries. Likewise, although 30 years of rapid and sustained economic expansion have gone by, over half the inhabitants of Central America -and three-quarters of those living in rural areas - do not have sufficient income to cover their essential needs as regards food, housing, clothing and basic services.

It should be noted that the exclusive pattern of development is not limited to the economic and social sphere. If it were possible to speak of a truly typical characteristic of the type of political interaction prevailing in most of the Central American countries, then this characteristic would be the absence of broad popular participation, reflected in the virtual exclusion of the masses (and especially the rural masses) from political activity. Neither the industrialization nor the urbanization which have taken place since the end of the war have been able to bring about a decisive change in the still essentially agricultural nature of these societies. With a few exceptions, the masses working in rural areas continue to be passive observers instead of organized actors in the evolution of the political systems. This exclusive feature has had a decisive influence both on the characteristics and the scope of various modernization projects attempted in the subregion.

Thus, with a few exceptions, the lack of effective participation on the part of the emerging sociaf classes has meant that they have not been in a position to counterbalance the weight of the traditional élites in the handling of public affairs, and this has sometimes further increased the tensions between the rapid social development and the slow institutional development in the political sphere. To put this in another way, the gap between the transformation which has taken place and the reinforcing of the political practices and 
Table 6

CENTRAL AMERICA: ESTIMATED INCIDENCE OF POVERTY TOWARDS 1980

\begin{tabular}{|c|c|c|c|c|c|c|c|c|c|}
\hline & \multicolumn{3}{|c|}{$\begin{array}{c}\text { Whole of Central } \\
\text { America }\end{array}$} & \multicolumn{3}{|c|}{$\tilde{C}_{\text {ostaRlca }}$} & \multicolumn{3}{|c|}{ El Salvadoi } \\
\hline & Total & Urban & Rural & Total & Urban & Rural & Total & Urban & Rural \\
\hline \multicolumn{10}{|c|}{ Thousands of persons } \\
\hline Total & 20696 & 8315 & 12381 & 2213 & 1011 & 1202 & 4747 & 2119 & 2678 \\
\hline In a state of poverty & 13178 & 3738 & 9440 & 549 & 138 & 411 & 3267 & 1221 & 2046 \\
\hline Extreme poverty & 8647 & 2130 & 6517 & 300 & 75 & 225 & 2427 & 943 & 1484 \\
\hline Basic needs not satisiied & 4531 & 1608 & 2923 & 249 & 63 & 186 & 840 & 278 & 562 \\
\hline Not in a state of poverty & 7518 & 4577 & 2941 & 1664 & 873 & 791 & 1530 & 898 & 632 \\
\hline \multicolumn{10}{|c|}{ Percentage breakdown } \\
\hline Total & 100.0 & 100.0 & 100.0 & 100.0 & 100.0 & 100.0 & 100.0 & 100.0 & 100.0 \\
\hline In a state of poverty & $63-7$ & 45.0 & 76.2 & 24.8 & 13.6 & 34.2 & 68.1 & 57.6 & 76.4 \\
\hline Extreme poverty & 41.8 & 25.6 & 52.6 & 13.6 & 7.4 & 18.7 & 50.6 & 44.5 & 55.4 \\
\hline Basic needs not satisfied & 21.9 & 19.4 & 23.6 & 11.2 & 6.2 & 15.5 & 17.5 & 13.1 & 21.0 \\
\hline \multirow[t]{3}{*}{ Not in a state of poverty } & 36.3 & 55.0 & 23.8 & 75.2 & 86.4 & 65.8 & 31.9 & 42.4 & 23.6 \\
\hline & \multicolumn{3}{|c|}{ Guatemala" } & \multicolumn{3}{|c|}{ Honduras } & \multicolumn{3}{|c|}{ Nicaragua } \\
\hline & Total & Urban & Rural & Total & Urban & Rural & Total & Urban & Rural \\
\hline \multicolumn{10}{|c|}{ Thousands of persons } \\
\hline Total & 7262 & 2485 & 4777 & 3691 & 1229 & 2462 & 2733 & 1471 & 1262 \\
\hline In a state of poverty & 5166 & 1168 & 3998 & 2515 & 540 & 1975 & 1681 & 671 & 1010 \\
\hline Extreme poverty & 2879 & 418 & 2461 & 2092 & 376 & 1716 & 949 & 318 & 631 \\
\hline Basic needs not satisfied & 2287 & 750 & 1537 & 423 & 164 & 259 & 732 & 353 & 379 \\
\hline Not in a state of poverty & 2096 & 1317 & 779 & 1176 & 689 & 487 & 1052 & 800 & 252 \\
\hline \multicolumn{10}{|c|}{ Percentage breakdown } \\
\hline Total & 100.0 & 100.0 & 100.0 & 100.0 & 100.0 & 100.0 & 100.0 & 100.0 & 100.0 \\
\hline In a state of poverty & 71.1 & 47.0 & 83.7 & 68.2 & 43.9 & 80.2 & 61.5 & 45.6 & 80.0 \\
\hline Extreme poverty & 39.6 & 18.8 & 51.5 & 56.7 & 30.6 & 69.7 & 34.7 & 21.6 & 50.0 \\
\hline Basic needs not satisfied & 31.5 & 30.2 & 32.2 & 11.5 & 13.3 & 10.5 & 26.8 & 24.0 & 30.0 \\
\hline Not in a state of poverty & 28.9 & 53.0 & 16.3 & 31.8 & 56.1 & 19.8 & 38.5 & 51.4 & 20.0 \\
\hline
\end{tabular}

Source: ECLAC, on the basis of data from the countries and CELADE (1981).

"Urban/rural population breakdown corresponds to figures from the 1979/1980 family income and expenditure survey.

${ }^{6}$ Urban/rural population breakdown corresponds to figures from the 1978/1979 family income and expenditure survey. 
institutions of a more complex society has contributed to the underlying instability of Central America.

To sum up, except in the case of Costa Rica the political interaction in Central America has generally been of an elitist nature and it has not been able to bring the most numerous population groups of the subregion into the project for the modernization of its societies.
Doing so would have meant perhaps the elimination, although possibly only gradually, of the factors of authoritarianism already referred to, and it would have been necessary to undertake the consistently postponed reforms aimed at fulfilling the legitimate aspirations of the groups which have so far been virtually excluded from the benefits of development.

\section{Recent events and the current economic crisis}

As already noted, Central America is experiencing a crisis of unprecedented depth and proportions. Economic activity has fallen off, considerable external imbalances exist as well as imbalances in the public sector, levels of saving and investment have slumped and there is increasingly less margin of action to overcome these imbalances and direct economic policy.

It may be assumed, in view of the increasingly high levels of open unemployment and underemployment, that the historical inequalities in Central American economies are becoming even more pronounced. The length of the depression and the limited capacity of some countries to contract external debt have made it necessary to adopt readjustment programmes - some of them within the framework of commitments with the International Monetary Fund - involving the adoption of unpopular economic policies.

Moreover, the aforementioned political upheavals affecting the region are closely linked with the economic phenomena described above, and perhaps all this means that there will be a breakdown in the "superimposed development" without there being any indication as yet of the likely characteristics of an alternative type of development. Moreover, the far from encouraging economic prospects already described hinder the social changes without which the political stability of a number of countries in the region is in jeopardy.

The depth of the crisis has generated a seemingly insuperable climate of demoralization. Awareness of the fact that many problems surpass the capacity of action of the constituted governments has given rise to uncertainty and even confusion, and the very foundations of the process of Central American integration are being worn away.

\section{The break with historical trends}

In 1977-1978 the trends briefly described above reached a turning point, at least as regards sustained economic growth. Since that two-year period, a progressive slowdown has occurred which finally led to negative rates in most countries in 1981 and 1983 and in all of them in 1982 (see figurei and table 1). The duration, intensity and peculiar characteristics of this situation have no precedent in the period since the war. Suffice it to say that, after 30 years of expansion of the five countries' per capita income (with only sporadic interruptions), there has been a sharp and generalized fall during the last five years. Although the shrinkage recorded in the economies in the preceding years came to an end in 1984 (with the exception of 
Nicaragua), in the case of most countries the outlook could in no way be described as one of reactivation. Thus, real per capita income at the end of 1984 in Costa Rica and Guatemala was barely equal to the 1972 figure; in Honduras it was equal to that for 1970, and in El Salvador and Nicaragua - where the situation was even more dramatic - it was similar to that of 1960 and 1965 respectively. It should be pointed out that the overall deterioration in the material standard of living is reflected not only by these figures but also by less tangible indicators, such as social harmony, personal security and the quality of life of the Central American population.

In addition, the process of economic integration, which had earlier allowed the downward fluctuations in the international economy to be offset, underwent a complete turnaround and became a factor which magnified the crisis. Due to the depth of the crisis - together with the prevailing political conditions and the lack of a strategy of subregional scope- the economic interdependence of the five countries has tended to become a mechanism which transmits recessionary economic forces.

The fact that the pronounced deterioration in the evolution of the economies has coincided with a period of increasing political upheaval may be functionally related to some of the characteristics of Central American societies which were mentioned previously. One of the many manifestations of those characteristics has led to a questioning of the social order, involving violent challenges to the status quo, and these, in turn, have given rise to violent responses which have contributed to a rapid polarization of positions in some countries, especially El Salvador and Nicaragua. There are many complex and mutually reinforcing interrelationships among the local political and economic factors and the way in which both intermix with external influences.

\section{The impact of exogenous phenomena}

It is no coincidence that the economic crisis has affected all of the countries, regardless of the level of social peace or upheaval prevailing in them, the economic policy objectives pursued or the different relations between the public and private sectors. All have been seriously affected by factors of external origin. This has been inevitable, because the common denominator affecting all the countries has been the deep recession in the international economy, which, as already noted, to a great extent determines the overall behaviour of the Central American economies and even imposes a limit upon their ability to grow. Now, the economic effect of the political crisis -discouragement of private investment, flight of capital, difficulties in attracting external financing - has been added to the effect of the world recession, and these have combined and reinforced one another to the point where they have produced an economic breakdown unlike any seen in Central America since the 1930s.

With respect to the effects of the disarray in the international economy, it may be recalled that, in addition to the industrialized countries' difficulties in 1978-1979 — low growth rates, high rates of inflation, decreased savings, lags in the application of technological innovationsthere was also a further increase in hydrocarbon prices in 1979. Even more importance should perhaps be attached to the attempts to modify economic policy made by some industrialized countries which have stressed the fight against inflation -with some success - and have resorted, inter alia, to restrictive monetary measures that have resulted in high interest rates. These policies have undoubtedly contributed to the slowdown of economic activity in the countries where they have been implemented, as well as in the world economy in general, with the resulting impact on the levels of international trade. This situation has weakened the demand for the Central American countries' traditional exports. Given the persistent international inflation (although since 1982 it has begun to decline), this weakness of demand has produced a marked deterioration in the terms of trade. An additional factor is that, in the financial sphere, the Central American countries have been affected by the high interest rates on their massive foreign debt and by their recent difficulties in gaining access to new external financing. 
Table 7

CENTRAL AMERICA: MAIN FOREING TRADE INDICATORS

\begin{tabular}{|c|c|c|c|c|c|c|c|c|c|}
\hline & 1976 & 1977 & 1978 & 1979 & 1980 & 1981 & 1982 & 1983 & 1984" \\
\hline Exports of goods & \multicolumn{5}{|c|}{ Growth rates } & & & & \\
\hline Value & 29.7 & 35.3 & -2.4 & 15.8 & 4.9 & -10.3 & -12.2 & -1.0 & 5.2 \\
\hline Volume & 5.1 & -0.9 & 2.6 & 13.0 & -6.4 & -2.7 & -8.3 & 0.8 & -1.4 \\
\hline Unit value & 23.4 & 36.5 & -4.9 & 2.5 & 12.1 & -7.8 & -4.3 & -0.9 & 6.7 \\
\hline \multicolumn{10}{|l|}{ Imports of goods } \\
\hline Value & 20.1 & 27.0 & 8.9 & 6.3 & 15.0 & -2.7 & -19.3 & -0.9 & 9.0 \\
\hline Volume & 22.0 & 20.5 & -1.6 & -5.5 & -3.3 & -7.1 & -23.7 & -1.8 & 6.0 \\
\hline Unit value & -1.6 & 5.4 & 10.7 & 12.5 & 18.9 & 4.7 & 5.8 & 0.9 & 2.8 \\
\hline Terms of trade (goods) & 25.4 & 29.5 & -14.1 & -8.9 & -5.7 & -11.9 & -9.5 & -1.8 & 3.8 \\
\hline \multicolumn{10}{|c|}{ Indexes } \\
\hline Terms of trade & 100.4 & 130.0 & 111.7 & 101.8 & 96.0 & 84.6 & 76.6 & 75.2 & 78.1 \\
\hline $\begin{array}{l}\text { Purchasing power of exports } \\
\text { of goods }\end{array}$ & 140.0 & 179.7 & 158.4 & 163.0 & 143.8 & 123.2 & 102.2 & 100.3 & 102.6 \\
\hline $\begin{array}{l}\text { Purchasing power of exports } \\
\text { of goods and services }\end{array}$ & 147.9 & 181.3 & $163-5$ & 169.4 & 151.1 & 126.9 & 108.2 & 106.6 & 108.5 \\
\hline
\end{tabular}

Source: ECLAC, on the basis of official data.

"Preliminary figures.

The figures in tables 7 and 8 speak for themselves. With the decline in the prices of virtually all the products exported by Central America and the continued upward pressure on the prices of imports (especially hydrocarbons in 1979-1980), ${ }^{5}$ by the end of 1984 the subregion's terms of trade had deteriorated by almost $50 \%$ since 1977, while the purchasing power of its exports had fallen by $30 \%$. In general terms, the foregoing means that if the 1977 purchasing power of exports had been sustained, the total value of exports in 1984 would have been $40 \%$ greater than it actually was, which would have added approximately $2.0 \%$ to the gross domestic product in the latter year.

Between 1978 and 1983, the terms of trade in goods have gone down in all of the countries,

'For the subregion as a whole, the relative share of petroleum in total imports rose from $4.4 \%$ in 1970 to $10.7 \%$ in $1976,18.7 \%$ in 1980 and $21.6 \%$ in 1981 before falling to $16.1 \%$ in 1984 . while the slight revival which occurred in 1984 (3.8\%) proved insufficient to reverse the decline which had taken place over the previous six years. In addition, there was a decline in the export volumes of some countries (and even the complete disappearance of some export products, such as nickel in Guatemala, which ceased to be exported because of lack of demand), as well as increasing difficulties in incorporating new lines of products into external sales, due to the market restrictions and protectionist measures which some industrialized countries have put into effect, and a considerable decrease in the exportation of some services such as tourism, due not only to the world economic recession, but also to non-economic factors in Central America.

On the other hand, productive activity in the Central American countries required imports, in spite of the recession, especially in order to meet the demand created by the increased public spending which was promoted by the 
Table 8

CENTRAL AMERICA: TERMS OF TRADE (GOODS)

\begin{tabular}{lrrrrrrrrr}
\hline & \multicolumn{8}{c}{ Growth rates } \\
\cline { 2 - 10 } & 1976 & 1977 & 1978 & 1979 & 1980 & 1981 & 1982 & 1983 & $1984^{\circ}$ \\
\cline { 2 - 10 } Total & 25.4 & 29.5 & -14.1 & -8.9 & -5.7 & $\mathbf{- 1 1 . 9}$ & -9.5 & -1.8 & 3.8 \\
Costa Rica & 19.7 & 30.6 & -17.7 & -1.6 & -2.8 & -14.8 & -10.2 & -4.5 & -0.7 \\
El Salvador & 39.6 & 47.3 & -26.2 & -8.2 & -15.4 & -12.6 & -0.8 & -7.1 & 13.1 \\
Guatemala & 28.6 & 33.4 & -5.1 & -15.7 & -2.7 & -8.7 & -13.0 & -2.4 & 1.2 \\
Honduras & 8.2 & 15.4 & -0.4 & -9.1 & -1.8 & -13.0 & -5.1 & -1.0 & 1.1 \\
Nicaragua & 21.9 & 16.2 & -13.8 & -16.0 & -3.4 & -11.7 & -10.4 & -12.7 & 8.1 \\
\hline
\end{tabular}

Source; ECLAC, on the basis of official data.

"Preliminary figures.

Table 9

CENTRAL AMERICA: BALANCE OF PAYMENTS TRADE DEFICIT IN MILUONS OF DOLLARS AND AS A PERCENTAGE OF GDP

\begin{tabular}{|c|c|c|c|c|c|c|c|c|c|c|}
\hline & 1975 & 1976 & 1977 & 1978 & 1979 & 1980 & 1981 & 1982 & 1983 & $1984 "$ \\
\hline \multicolumn{11}{|c|}{ Millions of dollars } \\
\hline Total & 570 & 427 & 432 & 887 & 653 & 1323 & 1572 & 906 & 898 & 1044 \\
\hline Costa Rica & 166 & 146 & 164 & 269 & 425 & 460 & 127 & -73 & 16 & 73 \\
\hline El Salvador & 79 & 12 & -29 & 234 & -2 & 51 & 237 & 218 & 151 & 207 \\
\hline Guatemala & 77 & 227 & 99 & 354 & 320 & 228 & 570 & 323 & 141 & 151 \\
\hline Honduras & 101 & 60 & 74 & 89 & 99 & 185 & 177 & 56 & 120 & 139 \\
\hline Nicaragua & 147 & -18 & 124 & -59 & -160 & 399 & 461 & 382 & 470 & 474 \\
\hline \multicolumn{11}{|c|}{ As a percentage of GDP } \\
\hline Total & 6.0 & 3.5 & 2.8 & 5.4 & 3.5 & $6 A$ & 6.8 & 5.1 & 4.8 & 5.3 \\
\hline Costa Rica & 8.7 & 6.1 & 5.3 & 7.6 & 10.5 & 10.1 & 4.8 & 3.0 & 0.5 & 2.1 \\
\hline El Salvador & 4.4 & 0.5 & 1.0 & 7.6 & 0.1 & 1.5 & 7.3 & 6.9 & 4.6 & 6.1 \\
\hline Guatemala & 2.4 & 5.2 & 1.8 & 5.8 & 4.6 & 2.9 & 7.2 & 4.3 & 1.8 & 1.9 \\
\hline Honduras & 9.7 & 4.7 & 4.8 & 4.9 & 4.6 & 7.4 & 7.0 & 2.2 & 4.5 & 5.5 \\
\hline Nicaragua & 9.5 & 1.0 & 5.5 & 2.9 & 7.7 & 17.1 & 18.2 & 18.7 & 23.0 & 20.0 \\
\hline
\end{tabular}

Source; ECLAC, on the basis of official data.

Note; Minus sign equals surplus.

"Preliminary figures. 
governments during the first year of the recession, partly in order to counteract the sluggishness of private investment. As a result, the trade deficit of the five countries went from US\$ 432 million in 1977 (equal to $2 \%$ of GDP) to nearly VS\$ 1.6 billion in 1981 (8.7\% of GDP), subsequently stabilizing at around US\$ 1 billion per year between 1982 and 1984 (5.4\% of GDP in" this latter year, albeit with considerable differences from one country to another) (see table 9). There was also a spectacular increase in debt servicing, attributable not only to increased borrowing but also — at least until mid-1984to soaring interest rates. External factor payments for the subregion as a whole rose, for example, from US\$280 million in 1977 to US\$ 980 million in 1984. This explains why the current account deficit grew from US\$ 573 million to more than US\$ 1.8 billion during the same period $(3.8 \%$ and $9-3 \%$ of GDP respectively) (see table 10).
During 1979-1980, Central America had considerable access to public and especially private international financing. The external support for Nicaragua's reconstruction programmes contributed significantly to this phenomenon, and these resources partially replaced internal savings, which tended to disappear rapidly due to public sector deficits and the flight of private capital. In 1977 only $12.6 \%$ of total savings came from external sources, but that figure had increased to $38.8 \%$ by 1981 and remained in excess of $35 \%$ in 1984 (see table 11). During the same period, the subregion's external public debt rose from US\$ 2.4 billion to slightly less than US\$ 15 billion, and limitations on several countries' capacity for additional borrowing became evident.

This last circumstance, combined with the constraints on the availability of new resources (the commercial banking system considers the

Table 10

\section{CENTRAL AMERICA: BALANCE OF PAYMENTS CURRENT ACCOUNT DEFICIT IN MILLIONS OF DOLLARS AND AS A PERCENTAGE OF GDP}

\begin{tabular}{|c|c|c|c|c|c|c|c|c|c|c|}
\hline & 1975 & 1976 & 1977 & 1978 & 1979 & 1980 & 1981 & 1982 & 1983 & 1984" \\
\hline \multicolumn{11}{|c|}{ Millions of dollars } \\
\hline Total & 700 & 455 & 573 & 1088 & 880 & 1690 & 2152 & 1715 & 1608 & 1806 \\
\hline Costa Rica & 218 & 203 & 226 & 364 & 554 & 654 & 408 & 305 & 358 & 371 \\
\hline El Salvador & 95 & 11 & -21 & 249 & 24 & 117 & 271 & 271 & 239 & 276 \\
\hline Guatemala & 65 & 79 & 37 & 271 & 180 & 178 & 567 & 376 & 224 & 314 \\
\hline Honduras & 125 & 115 & 139 & 170 & 212 & 331 & 321 & 249 & 260 & 311 \\
\hline Nicaragua & 197 & 47 & 192 & 34 & 90 & 407 & 585 & 514 & 527 & 517 \\
\hline \multicolumn{11}{|c|}{ As a percentage of GDP } \\
\hline Total & 7.4 & 3.7 & 3.8 & 6.6 & 4.7 & 8.1 & 11.6 & 9.6 & 8.6 & 9.3 \\
\hline Costa Rica & 11.4 & 8.4 & 7.4 & 10.3 & 13.7 & 14.3 & 15.6 & 12.6 & 11.9 & 10.9 \\
\hline El Salvador & 5.3 & 0.5 & 0.7 & 8.1 & 0.7 & 3.4 & 8.1 & 8.6 & 7.3 & 8.1 \\
\hline Guatemala & 2.1 & 1.8 & 0.7 & 4.5 & 2.6 & 2.3 & 7.2 & 5.0 & 2.9 & 4.0 \\
\hline Honduras & 12.0 & 8.9 & 9.0 & 9.3 & 9.8 & 13.1 & 15.8 & 9.6 & 9.9 & 12.3 \\
\hline Nicaragua & 12.7 & 2.5 & 8.6 & 1.7 & 4.3 & 17.4 & 27.1 & 25.1 & 25.8 & 21.8 \\
\hline
\end{tabular}

Source: ECLAC, on the basis of official data,

Note: Minus sign equals surplus.

"Preliminary figures. 
Table 11

CENTRAL AMERICA: EVOLUTION OF INVESTMENT AND SAVING

(Millions of constant 1970 dollars)

\begin{tabular}{|c|c|c|c|c|c|c|c|c|c|c|c|c|c|c|c|c|}
\hline & \multicolumn{2}{|c|}{1977} & \multicolumn{2}{|c|}{1978} & \multicolumn{2}{|c|}{1979} & \multicolumn{2}{|c|}{1980} & \multicolumn{2}{|c|}{1981} & \multicolumn{2}{|c|}{1982} & \multicolumn{2}{|c|}{1983} & \multicolumn{2}{|c|}{ 1984" } \\
\hline & Value & $\%$ & Value & $\%$ & Value & $\%$ & Value & $\%$ & Value & $\%$ & Value & $\%$ & Value & $\%$ & Value & $\%$ \\
\hline \multicolumn{17}{|l|}{ Central A merica } \\
\hline Gross domestic product & 10091 & 100.0 & 10519 & 100.0 & 10535 & 100.0 & 10624 & 100.0 & 10492 & 100.0 & 10049 & 100.0 & 10015 & 100.0 & 10170 & 100.0 \\
\hline Gross domestic investment & 2218 & 22.0 & 2231 & 21.2 & 1893 & 18.0 & 1969 & 18.5 & 1808 & 17.2 & 1405 & 14.0 & 1439 & 14.4 & 1529 & 15.0 \\
\hline Domestic saving & 1939 & 19.2 & 1719 & 16.3 & 1548 & 14.7 & 1409 & 13.3 & 1106 & 10.5 & 871 & 8.7 & 949 & $9-5$ & 993 & 9.7 \\
\hline External saving & 279 & 2.8 & 512 & 4.9 & 345 & 3.3 & 560 & 5.2 & 702 & 6.7 & 534 & 5.3 & 490 & 4.9 & 536 & 5.3 \\
\hline $\begin{array}{l}\text { External saving/total saving } \\
\text { Costa Rica }\end{array}$ & & 12.6 & & 22.9 & & 18.2 & & 28.4 & & 38.8 & & 38.0 & & 34.1 & & 35.1 \\
\hline Gross domestic investment & 554 & 28.0 & 552 & 26.3 & 603 & 27.4 & 643 & 29.0 & 400 & 18.4 & 298 & 14.8 & 373 & 18.1 & 423 & $19-6$ \\
\hline Domestic saving & 443 & 22.4 & 399 & 16.0 & 386 & 17.5 & 421 & 19.0 & 270 & 12.4 & 204 & 10.1 & 266 & 12.9 & 315 & 14.6 \\
\hline External saving & 111 & 5.6 & 153 & 7.3 & 217 & 9.9 & 222 & 10.0 & 130 & 6.0 & 94 & 4.7 & 107 & 5.2 & 108 & $5-0$ \\
\hline $\begin{array}{l}\text { External saving/total saving } \\
\text { El Salvador }\end{array}$ & & 20.0 & & 27.7 & & 36.0 & & 34.5 & & 32.5 & & 31.5 & & 28.7 & & 25.5 \\
\hline Gross domestic product ${ }^{6}$ & 2176 & 100.0 & 2316 & 100.0 & 2276 & 100.0 & 2079 & 100.0 & 1906 & 100.0 & 1800 & 100.0 & 1786 & 100.0 & 1813 & 100.0 \\
\hline Gross domestic investment & 531 & 24.4 & 547 & 23.6 & 422 & 18.5 & 287 & 13.8 & 276 & 14.5 & 234 & 13.0 & 240 & 13.4 & 257 & 14.2 \\
\hline Domestic saving & 542 & 24.9 & 409 & 17.7 & 428 & 18.8 & 287 & 13.8 & 185 & 9.7 & 148 & 8.2 & 165 & 9.2 & 165 & 9.1 \\
\hline External saving & -11 & -0.5 & 138 & 5.9 & -6 & -0.3 & - & - & 91 & 4.8 & 86 & 4.8 & 75 & 4.2 & 92 & 5.1 \\
\hline Gross domestic product & 3571 & 100.0 & 3750 & 100.0 & 3926 & 100.0 & 4074 & 100.0 & 4101 & 100.0 & 3957 & 100.0 & 3850 & 100.0 & 3858 & 100.0 \\
\hline Gross domestic investment & 611 & 17.1 & 674 & 18.0 & 585 & 14.9 & 499 & 12.2 & 575 & 14.0 & 465 & 11.8 & 384 & 10.0 & 386 & 10.0 \\
\hline Domestic saving & 592 & 16.6 & 544 & 14.5 & 498 & 12.7 & 440 & 10.8 & 385 & 9.4 & 347 & 8.8 & 316 & 8.2 & 294 & 7.6 \\
\hline External saving & 19 & 0.5 & 130 & 3.5 & 87 & 2.2 & 59 & 1.4 & 190 & 4.6 & 118 & 3.0 & 68 & 1.8 & 92 & 2.4 \\
\hline $\begin{array}{l}\text { External saving/total saving } \\
\text { Honduras }\end{array}$ & & 3.1 & & 5.2 & & 14.9 & & 11.8 & & 33.0 & & 25.4 & & 17.7 & & $23-8$ \\
\hline Gross domestic product & 1116 & 100.0 & 1199 & 100.0 & 1281 & 100.0 & 1316 & 100.0 & 1331 & 100.0 & 1307 & 100.0 & 1301 & 100.0 & 1337 & 100.0 \\
\hline Gross domestic investment & 203 & 18.2 & 323 & 26.9 & 342 & 26.7 & 383 & 29.1 & 315 & 23.7 & 208 & 15.9 & 224 & 17.2 & 261 & 19.5 \\
\hline Domestic saving & 139 & 12.5 & 248 & 20.7 & 258 & 20.1 & 267 & 20.3 & 209 & 15.7 & 127 & 9.7 & 139 & 10.7 & 163 & 12.2 \\
\hline External saving & 64 & 5.7 & 75 & 6.2 & 84 & 6.6 & 116 & 8.8 & 106 & 8.0 & 81 & 6.2 & 85 & 6.5 & 98 & 7.3 \\
\hline $\begin{array}{l}\text { External saving/total saving } \\
\text { Nicaragua }\end{array}$ & & 31.5 & & 23.2 & & 24.6 & & 30.3 & & 33.7 & & 38.9 & & 37.9 & & 37.5 \\
\hline Gross domestic product" & 1253 & 100.0 & 1155 & 100.0 & 850 & 100.0 & 935 & 100.0 & 984 & 100.0 & 973 & 100.0 & 1018 & 100.0 & 1003 & 100.0 \\
\hline Gross domestic investment & 319 & 25.5 & 135 & 11.7 & -59 & -6.9 & 157 & 16.8 & 242 & 24.6 & 200 & 20.5 & 218 & 21.4 & 202 & 20.1 \\
\hline Domestic saving & 223 & 17.8 & 119 & 10.3 & -22 & -2.6 & -6 & -0.6 & 57 & 5.8 & 45 & 4.6 & 63 & 6.2 & 56 & 5.6 \\
\hline External saving & 96 & 7.7 & 16 & 1.4 & $\cdot 37$ & -4.3 & 163 & 17.4 & 185 & 18.8 & 155 & 15.9 & 155 & 15.2 & 146 & 14.5 \\
\hline External saving/total saving & & 30.1 & & 11.9 & & -62.7 & & 103.8 & & 76.4 & & 77.5 & & 71.1 & & 72.3 \\
\hline
\end{tabular}

Source: ECLAC, on the basis of official data.

"Preliminary figures.

At market prices. 
subregion to be of high financial and political risk, while official sources have tended to diminish due to the austerity policies of the donor countries), has created serious difficulties since 1981 in obtaining net financing, and in 1982 external savings - far from offsetting the drop in national savings - showed the same downward trend.

It should be mentioned that the majority of the countries' balance of payments have recorded increases in net capital inflows since 1981, particularly in 1983 when these came to almost VS\$ 2 billion. Approximately half such income did not represent injections of currency, however: it was the result of renegotiations of payments due on the existing external debt, particularly in Costa Rica and Nicaragua (ECLAC, 1985).

Moreover, those countries which obtained access to a greater flow of official funding, particularly of a bilateral nature (Costa Rica, El Salvador and, to a lesser extent, Honduras), have had to accept increasingly strict conditionality, basically with regard to economic policy, but on some occasions even affecting other aspects of national activity too. During 1984 the International Monetary Fund, which is supporting readjustment programmes in three countries, ceased its disbursements to two of them (Guatemala and Honduras) because they had failed to meet the quantitative goals set, while in the case of the third country (Costa Rica) no final agreement had yet been reached at the time of writing (March 1985) on the renewal of the programme which had come to an end in December 1984.
Finally, a further phenomenon of considerable importance which made itself sharply felt during this period was the intense and persistent flight of capital throughout the subregion (in some countries more than in others) due to economic and especially noneconomic factors. The identifiable deposits of Central American citizens in United States banks alone (excluding their branches in the Bahamas, Panama and other banking havens), grew by more than US\$ 1.4 billion between mid1979 and 1984. The breakdown by countries is given in table 12.

It should be noted that the fluctuation in the size of these deposits provides a rough indicator of the scale of capital flight in the five countries mentioned. On the one hand, part of the increase represents the reinvestment of interest earned by these same deposits. On the other, this figure naturally fails to include investments made by Central Americans during the last five-year period in real estate and securities in the United States, or any other type of investment made in other countries open to capital.

At a rough estimate, between 1979 and 1984 this flight represented between US\$ 2 billion and US\$ 2.5 billion for the five countries in the region. Naturally, this worsened each country's external position, and had a decisive influence in the slump in economic activity. Paradoxically, the exhaustion of the countries' international monetary reserves at the beginning of the recessionary period and the high level of external indebtedness recorded facilitated this capital flight.

Table 12

\section{CENTRAL AMERICA: DEPOSITS OF CENTRAL AMERICAN CITIZENS IN THE UNITED STATES FINANCIAL SYSTEM}

(Millions of dollars)

$\begin{array}{lcccccc} & \text { Total } & \text { Guatemala } & \text { El Salvador } & \text { Honduras } & \text { Nicaragua } & \text { Costa Rica } \\ \text { June 1979 } & 1104 & 318 & 265 & 147 & 171 & 203 \\ \text { June 1984 } & 2525 & 850 & 536 & 471 & 140 & 528 \\ \text { Variation } & 1421 & 532 & 271 & 324 & -31 & 325\end{array}$

Source: Federal Reserve System (1979 and 1984) and Treasury Department (1980 and 1984). 
Furthermore, exogenous factors not only had an impact on the evolution of the economies, but also influenced political events. Towards the end of the 1970s significant changes occurred in the political interaction of the subregion, especially in Nicaragua. Just as the long period of postwar economic expansion had reached a turning point, the social and political structures too had to undergo a major shift. These events gave rise to a heterogeneous alliance which challenged the ruling régime in Nicaragua. It was no accident, however, that the changes in Nicaragua -like those in Guatemala, El Salvador and Honduras in the 1940s-coincided with a United States foreign policy aimed at promoting orderly change based on principles prized by the latter country. Thus, during a brief interlude the geopolitical boundaries referred to earlier were extended, and the challenge launched in one of the countries against the traditional development model became viable.

\section{The challenge to the "superimposed development" model}

The programme adopted by the Government of National Reconstruction of Nicaragua departs from the traditional norms. In a different context, the events in El Salvador also deviate from the model of "superimposed development", since they have given rise to changes which, in one form or another, alter the pre-existing structures. It could even be said that, under the twofold onslaught of the economic crisis and the threat to the status quo, it is unlikely that the pre-existing structures in some countries will be able to survive without fundamental adjustments. This in no way predetermines the nature of the social organizations which might eventually replace the preceding ones, nor their ideological leanings; ;t only means that the postwar model which has been in effect for more than 30 years may have run its course.

Some of the economic phenomena which are the subject and object of the crisis clearly illustrate the above. One such phenomenon is capital accumulation. Investment has been shrinking markedly since 1978 both as a result and as a cause of the contraction in economic activity, the drop in domestic savings, the flight of capital and the reaction of the private sector to the political and social tensions affecting the subregion. Table 11 shows that the domestic savings of the five countries fell from $19.2 \%$ to $9.7 \%$ of the gross domestic product between 1977 and 1984: a serious situation for countries which are attempting to develop. Private investment also suffered a marked setback, and it diminished in all of the countries. The subregional coefficient of private investment fell from $13-4 \%$ in 1977 to less than $8 \%$ in 1984, while in the countries experiencing civil unrest, the coefficient of private capital formation has fallen by more than $50 \%$ in the last seven years. The public sector made an effort to counteract this decrease (thereby accentuating another long-standing imbalance in the Central American economies: the public finance deficit) but it was not enough; the coefficient of total investment declined in all the countries and tended to create bottlenecks in areas where public spending cannot substitute for private investment.

The deliberate efforts made by governments to counteract the reduction in economic activity, at a time when there was a downward trend in tax revenues, caused the portion of the subregional GDP represented by public spending to increase from $17.7 \%$ in 1977 to $21.3 \%$ in 1981, while the taxation rate decreased from $12.9 \%$ to $11.6 \%$ during the same period. As a result of the asymmetry in the patterns of expenditure and income, the aggregate deficit of the five governments rose from 460 million Central American pesos in 1977 (3\% of GDP) to approximately 1.6 billion in 1984 (8.0\% of GDP) (see table 13). Since there was not enough external financing to cover the deficits, domestic financing was used, but this expedient indirectly exacerbated the disequilibrium in the balance of payments - through the imported component of expenditure - and in some cases absorbed most of the expansion in domestic credit, thereby taking away resources from the private national sectors. Thus, forces came into play which are tending to destroy, or already have destroyed, the traditional stability of prices and exchange rates in the countries of the subregion. This is another manifestation of the gradual functional impoverishment of the pre-existing structures. 
Table 13

CENTRAL AMERICA: CENTRAL GOVERNMENT DEFICITS

\begin{tabular}{|c|c|c|c|c|c|c|c|c|c|}
\hline & 1976 & 1977 & 1978 & 1979 & 1980 & 1981 & 1982 & 1983 & $1984^{\circ}$ \\
\hline \multicolumn{10}{|c|}{ Millions of Central American pesos } \\
\hline Total & 579 & 459 & 789 & 910 & 1470 & 1609 & 1462 & 1709 & 1571 \\
\hline Costa Rica & 150 & 136 & 211 & 324 & 418 & 113 & 78 & 157 & 113 \\
\hline El Salvador & 27 & -60 & 52 & 36 & 198 & 232 & 249 & 313 & 244 \\
\hline Guatemala & 225 & 98 & 138 & 254 & 446 & $674^{\prime}$ & 459 & 301 & 316 \\
\hline Honduras & 84 & 102 & 150 & 140 & 243 & 248 & 382 & 343 & 374 \\
\hline Nicaragua & 93 & 183 & 238 & 156 & 165 & 242 & 294 & 595 & 524 \\
\hline \multicolumn{10}{|c|}{ As a percentage of GDP } \\
\hline Total & 4.7 & 3.0 & 4.8 & 4.9 & 7.1 & 8.7 & 8.2 & 9.1 & 8.0 \\
\hline Costa Rica & 6.2 & 4.4 & 6.0 & 8.0 & 9.2 & 4.3 & $3-2$ & 5.2 & 3.3 \\
\hline El Salvador & 1.1 & -2.1 & 1.7 & 1.0 & 5.7 & 7.1 & 7.9 & 9.6 & 7.2 \\
\hline Guatemala & 5.2 & 1.8 & 2.3 & 3.7 & 5.7 & 8.5 & 6.0 & 3.9 & 4.2 \\
\hline Honduras & 6.5 & 6.6 & 8.2 & 6.5 & 9.5 & 9.9 & 14.8 & 13.0 & 14.8 \\
\hline Nicaragua & 5.0 & 8.2 & 11.7 & 7.5 & 7.1 & 11.2 & 14.4 & 29.1 & 22.1 \\
\hline
\end{tabular}

Source; ECLAC, on the basis of official data.

Note: Minus sign equals surplus.

"Preliminary figures.

\section{The consequences for intra-Central American co-operation}

The constraints of the external sector -reflected in the shortage of foreign exchangehave worsened to such an extent that, as from 1981, the countries with deficits in intraregional trade have even had difficulties in covering their debit balances. Initially, the central banks of the surplus countries extended bilateral lines of credit, and later a subregional mechanism was established to deal with the same problem multilateraly (the Central American Common Market Fund). However, when these avenues were exhausted ${ }^{6}$ - and

\footnotetext{
${ }^{6}$ At the end of December 1984, the bilateral debts contracted by the countries in order to keep up their trade in previous years came to over US\$ 380 million, a debt so large that it exhausted the financing capacity both of the countries enjoying a surplus in this trade and of the multilateral mechanisms mentioned. See the periodic reports of the Central American Clearing House.
}

when sufficient backing from the international community was not forthcoming - the lack of foreign exchange began to limit intra-Central American trade.

The response of some countries to the constraints on their external sector was to adopt exchange measures (variations in parity, adoption of multiple rates or of controls on the movement of foreign exchange) which affected the terms of trade at the inter-Central American level and in some cases limited the volume of commercial transactions. As a result of all these phenomena, intra-regional trade ceased to play its traditional role as a factor capable of offsetting cyclical lows in extra-regional trade and became one more victim of the crisis in the external sector. Thus, the value of this trade has declined systematically -from 1.13 billion Central American pesos in 1980 to 742 million in 1984- and its relative share of the 
subregion's total exports shrank from $23.1 \%$ to $18.5 \%$ in the same period (see table 14 ).

One of this situation's innumerable effects on the productive apparatus was that the degree of industrialization - which, as already noted, had increased consistently between 1950 and 1978 - stagnated, diminishing from $17.1 \%$ in 1978 to $16.2 \%$ in 1982 and $16 \%$ in 1984. In other words, after its expansion had been more dynamic than that of the economy as a whole during the boom, industrialization performed even less dynamically than the economy as a whole during the recession.

Despite the fact that the Central American governments have traditionally been, and continue to be, successful in keeping the sphere of economic co-operation separate from the sphere of political relations, the growing ideological heterogeneity now poses a latent threat that political differences will overflow into the sphere of economic co-operation precisely at the time when intra-regional cooperation is most needed in order to mitigate the effects of the external sector problems. In addition, the danger of internationalization of intra-regional conflicts could lead to a greater fragmentation of Central America and a repetition of painful historical episodes.

Table 14

\section{CENTRAL AMERICA: TOTAL VALUE OF INTRA-REGIONAL TRADE AND RELATIVE SHARE IN TOTAL EXPORTS}

\begin{tabular}{|c|c|c|c|c|c|c|c|c|}
\hline & 1977 & 1978 & 1979 & 1980 & 1981 & 1982 & 1983 & 1984" \\
\hline \multicolumn{9}{|c|}{$\begin{array}{l}\text { Value of exports to the rest of Central America } \\
\text { (millions of Central American pesos) }\end{array}$} \\
\hline Total & 785355 & 862720 & 891731 & 1129160 & 936792 & 762850 & 757706 & $742 \quad 138$ \\
\hline Costa Rica & 173802 & 178679 & 175354 & 270328 & 238023 & 164592 & 187089 & 175459 \\
\hline El Salvador & 211653 & 233569 & 266601 & 295796 & 206484 & 174229 & 168101 & 176515 \\
\hline Guatemala & 222465 & 254971 & 299602 & 403728 & 355501 & 320067 & 308155 & 289851 \\
\hline Honduras & 43449 & 49199 & 60011 & 83889 & 65912 & 51876 & 61377 & 57830 \\
\hline Nicaragua & 133986 & 146302 & 90163 & 75419 & 70872 & 52086 & 32984 & 42983 \\
\hline \multicolumn{9}{|c|}{$\begin{array}{l}\text { Ratio of value of exports to the rest of Central America } \\
\text { to value of total exports (percentages) }\end{array}$} \\
\hline Total & 19.0 & 21.4 & 19.1 & 23.1 & 21.3 & 19.8 & 19.8 & 18.5 \\
\hline Costa Rica & 21.0 & 20.7 & 18.6 & 27.0 & 23.7 & 18.9 & 21.5 & 18.3 \\
\hline El Salvador & 21.7 & 29.1 & 23.5 & 27.5 & 25.9 & 24.7 & 23.0 & 23.3 \\
\hline Guatemala & 19.1 & 23.3 & 24.5 & 26.6 & 27.4 & 26.7 & 28.2 & 25.5 \\
\hline Honduras & 8.2 & 7.9 & 7.9 & 9.9 & 8.4 & 7.7 & 8.8 & 7.5 \\
\hline Nicaragua & 21.1 & 22.6 & 14.6 & 16.7 & 14.0 & 12.8 & 7.7 & 11.0 \\
\hline
\end{tabular}

Source: S1ECA.

"Preliminary figures. 


\section{Short-term prospects}

As indicated in the previous chapter, the majority of Central American countries have been suffering for five or six years in succession from negative rates of growth and pronounced imbalances both in the external sector and in public finances. Almost all of them undertook adjustment programmes towards 1981, once their international monetary reserves had been exhausted. These policies have been applied with varying intensity and in different fashion from one country to another. Generally speaking, imports fell off sharply -in some cases as a result of exchange adjustments, in others simply as a reflection of quantitative restrictions and depressed demand- public expenditure fell off, and restrictive credit policies were applied together with tight wages policies. In a number of cases, tax procurement also increased and payments due on the external debt were restructured. Even Nicaragua adopted a set of measures after 1984 -belatedly and without International Monetary Fund approval- which pursued the same aims.

Nevertheless, in 1984, two or more years since the adjustments were undertaken, the outlook remains unpromising. In four out of the five economies the per capita gross domestic product has recorded continual declines, and in all of them (albeit to differing extents) domestic and external financial imbalances continued to be recorded (in the case of two countries the IMF even interrupted disbursements of the stand-by credits which had been granted, as the countries had failed to comply with the programmes agreed upon).

At the beginning of 1985 , then, what is the likelihood of the subregion's economies adjusting to the new international circumstances and succeeding in constructing a new platform for reactivating production?

\section{External and domestic constraints}

As 1985 began, the future of the Central American economies was fraught with uncertainty. The brisk revival which had taken place in the United States economy during the previous two years had not as yet been transmitted with similar intensity to the remaining industrialized countries, and even less so to the developing countries, especially the small agricultural export economies such as those of Centrai America. Doubt was also harboured as to whether the revival would prove lasting.

These phenomena could not fail to have a powerful influence on the evolution and features of the Central American countries' external trade. During 1983 and 1984, despite the recovery in the United States, no significant improvement occurred in the region's terms of trade. This is an exception to historical experience, as generally the prices of commodities have risen during the upward phase of international economic cycles.

These phenomena may be linked to the transformations which have taken place in the international economy. New technologies - particularly the application of microelectronics and biogenetics, together with the introduction of new materials (fibre optics and high-temperature ceramics and plastics) alter comparative advantages throughout the world, transform trade flows and probably have an adverse impact upon small agricultural export economies, such as those of Central America. One illustration of this is the reversal which has occurred in the redeployment of the textiles industry from the developed countries towards the Third World, which may be attributed to technological innovations in the automation of manufacturing processes. This phenomenon is in addition to the well known income-inelasticity of the demand on international markets for the commodities exported by Central America. In addition, the overvaluation of the dollar, in which the prices of the commodities exported by Central America are quoted, further aggravated this trend. 
The uncertainty affecting the subregion's external trade is also reflected in the financial sphere. It would seem likely that in the foreseeable future the capital accounts of Central America's balances of payment will display quite different features from those recorded in previous decades. Firstly, there is little likelihood of net external funds of similar size to those of the 1970s being mustered. On the one hand, international private banks appear to be extremely reluctant to commit fresh funds in a subregion in which high risks are considered to prevail; on the other hand, commitments originating from external debt servicing are so high that the possibility of the region becoming a net exporter of capital cannot be discounted.

Secondly, even if the countries of the subregion obtain access to increased external public financing, the funds would probably be subject to even stricter conditions, with a consequent impact both on economic policy and other policy areas outside the economic sphere. This circumstance represents a far clearer tradeoff in the application of economic policy than has hitherto been the case: the cost of formulating a reactivation policy without having access to sufficient external funds, as against the possible costs - naturally of another kind - of obtaining such funds, but on such terms that the vulnerability of the economies would be maintained and perhaps even increased.

Finally, the majority of countries are facing an equally unprecedented problem regarding the restructuring of commitments deriving from the external debt. The conditions on which agreement is reached with regard to servicing the debt will be one of the factors determining the capacity of the Central American economies to import and consequently to grow. Here again, it is hard to make any predictions in this respect.

Uncertainty over factors of domestic origin comes on top of the unsettled trends in the international economy. Perhaps the most

'This phenomenon is aggravated by the fact that as a result of the application of various mechanisms which vary from one country to the next (stabilization bonds, guarantee funds, underwriting of loans) the public sector has virtually taken over the risk for the external private debt, and consequently, ¡ none way or another, governments have assumed responsibility for servicing the total external debt. significant of these factors are the social and political conflicts taking place in the subregion. It would be Utopian to consider reactivating the economies on the basis of a revival of domestic savings and investment —which are in themselves inadequate- without having succeeded in correcting the prevailing climate of political instability. This in turn requires changes in the patterns of political interaction in most Central America countries.

Consequently, as long as ideological polarization persists and spills over into violent conflict, and as long as no success is achieved in integrating and improving the participation of the various sectors of the population in political activity, there is little likelihood of a return to the social harmony which, today more than ever, is a pre-requisite for achieving targets of material well-being. Unless this is achieved, the flight of private capital will continue together with the erosion of the capital stock, thereby threatening the continuity of domestic mechanisms for generating savings and investments.

In such circumstances, neither is it feasible to envisage a simple process allowing for concerted support for the policy of economic reactivation. The present climate of ideological and conceptual polarization, together with the widespread tendency to resort to violence in order to settle conflicts in a number of countries, and the increased intensity of struggles for a share in the declining profits furnished by the economies, make it singularly difficult to achieve even minimum consensuses on any development project. Moreover, the tensions described above have led to a considerable diversion of resources towards expenditure on defence and security at a time when the subregion's governments should utilize a maximum of their meagre resources in protecting their populations' standards of living. In this respect, domestic friction as well as dissension between countries hamper economic revival and prevent any improvement in the climate for intra-regional co-operation.

To sum up, it is difficult to make any forecast as to the likely evolution of the Central American economies. On the one hand, the exhaustion of their international monetary reserves, the burden of the external debt, the shrinkage in imports and the depressed levels of 
all macroeconomic variables (consumption, savings, investment, employment) considerably narrow the margin of action available to economic policy; on the other hand, the restrictions of external and subregional origin affecting Central American development are subject to a whole range of factors which further heighten the uncertainty looming over all the countries. Thus, the domestic and external economic and non-economic circumstances which determined the evolution of Central American economies and societies during the $\$ 0$ years after the Second World War have undergone a change, and this will undoubtedly call for different responses from those adopted in the past if the subregion is to overcome the obstacles which nowadays virtually cancel out any possibility of expansion and transformation of its economies.

\section{The growing conceptual polarization}

One of the many consequences of the international economic crisis has been the collapse of historical paradigms. Thus, just as doubt is being cast on the Keynesian theses which dominated governmental action in the industrialized countries for more than 30 years, the outmoded methods used to stimulate the development of the Third World economies are also being questioned. A major debate is underway over the supposed decadence of the "discipline" of development. It is asserted by some that developmentalist patterns — which would appear to include the "idées-force" repeatedly set out by the Secretariat of ECLAC have proved ineffective, and consequently a variety of credos of either neoclassical or Marxist bent are being put forward (Hirschman, 1981, pp. 5 to 19). With regard to Central America, the debate follows lines parallel to the already mentioned ideological polarization.

Moreover, in a number of industrialized economies, and particularly in the United States of America, there has occurred what some see as a reaction to the excesses committed since the 1930s with regard to welfare policy, the expansion of public services, the rise in tax coefficients and increasing regulation of a variety of private activities (Gilder, 1981 and Murray, 1984). This growing conservatism in the sphere of economic policy advocates the reduction of the State's role (which, among other things, leads to a lower tax burden and a shrinkage of public services); increased reliance upon the market in resource allocation; the encouragement of saving and private investment, together with the elimination or at least the reduction of controls and regulations. In the cultural and civic spheres policies which make an appeal to traditional values are being advocated (Kristoal, 1978 and Podhoretz, 1980). Naturally, this set of ideas has found supporters and imitators in other parts of the world, including of course the countries of Central America.

These two phenomena - the collapse of established paradigms as a result of the economic crisis and the gradual rise of the attitudes towards social and economic organization prevailing within some advanced societies - point to a clear conceptual polarization over the way in which the process of economic development should be handled. Not only does this produce new cleavages between the various social groups, but it has also led to a number of international financial bodies - bothmultilateral and bilateral- taking part in the debate and recently propagating in Central America variations of the fashionable theory as to how to adjust and reactivate the economies.

The conjunction of these phenomena has given rise to two opposing strategies for bringing about reactivation. The first of these proposes "opening up" the Central American economies to international trade and financial flows and adopting a set of macroeconomic policies designed to give the productive apparatus an export-oriented bias, in order that the market forces may direct it towards increased insertion into the international economy, on the basis of the comparative advantages possessed by the region. This "opening up" would ideally go hand in hand with the encouragement of private investment as well as, on occasion, a reduction in the role of the public sector, especially with a view to eliminating obstacles to the market signals. The advocates of this approach claim that the recovery of the industrialized economies would spread vigorously to the Central American economies 
through the many linkages which would be established.

Advocates of the opposing view are to be found among those who, after having observed the magnitude of the adverse factors in the Central American external sector during recent years, propose that the subregion's economies should be further isolated from the vicissitudes of the international economy, and that the State should play a greater role to counterbalance the performance of the private sector and offset the recessionary impact of the depression.

To sum up, what is taking place is the ageold debate, but under new circumstances, with perhaps more extreme and doctrinaire approaches than in the past. These circumstances further worsen the climate of uncertainty so often mentioned.

\section{Alternative prospects}

Forecasts as to the likely evolution of the Central American economies depend at least partly upon the stance adopted by the author. In the view of some authors, the logical outcome of advocating the unrestricted operation of market mechanisms in resource allocation, of reducing the various ways in which the State plays a guiding role, of encouraging both national and international private investment and eliminating any barriers to such investments, would be for the Central American economies to be pulled along by the renewed expansion of the international economy - mainly under the pull of the developed economies and in particular that of the United States of America- towards a new era of prosperity, founded this time on advanced technology and a number of tertiary activities. In other words, the same reasoning that would bring about the reactivation of the central economies would cause its dynamizing impact to spill over into the peripheral economies, through a new worldwide scheme of comparative advantages (Nau, 1984-1985). Of course, it is acknowledged that there are obstacles which might mean that not all countries could reap maximum benefits from this momentum (for example, the high level of external indebtedness of some countries), but it is claimed that it is possible to lower and overcome these hurdless by means of timely negotiations and the application of suitable policies.

A different forecast would involve recognizing the possibility that the recent expansion in the economies of the Organization for Economic Co-operaton and Development (OECD) might fail to maintain itself, ${ }^{8}$ or that its dynamic impact might not necessarily be felt in the peripheral economies. At least as far as Central America is concerned, there are factors of domestic origin which decidedly upset the free operation of the market mechanisms. The dynamizing effects traditionally associated with economic integration have gradually dwindled away in recent years as a result of the very depth of the crisis. It follows that in view of the uncertain outlook for the region, it would be realistic to assume that the period necessary for the Central American economies and societies to adjust to the new circumstances -in the external and regional environment as well as within each country - might be quite long. Indeed, if it turned out that the international economic crisis was merely a depressive cycle -albeit the deepest since the war- the positive impact, as already noted in Central America in 1984, would be extremely limited during the next two years, in view of the heavy burden of external indebtedness, the exhaustion of international monetary reserves and the major upsets which the recession has caused to the subregion's productive capacity and social structure.

The vital need to undertake structural transformations in order to adapt to a changing international economy will necessarily take a long time. In recent years the Central American countries have realized that the development of new export activities cannot be achieved either by decree or instantaneously: it requires changes of attitude on the part of entrepreneurs and workers, trial periods which may occasionally be long, changes in methods of production and marketing, and lengthy periods before new investment bears its fruit. Even if an economic strategy with a smaller element of self-

\footnotetext{
${ }^{8} \mathrm{Nau}$ (1984-1985) indicates that, if the United States fiscal deficit is not brought down, that country's economy will shortly enter a new recessionary cycle, caused by high interest rates and the shrinkage of private investment.
} 
determination were chosen, it would also require a long period before making itself felt. The need to simultaneously address the whole set of problems facing the region - moving forward in the painful but unavoidable task of adjustment, restoring acceptable levels of saving and investment, reactivating production and providing even a minimal response to popular demands which have long been put off- merely serves to complicate the outlook and confirms that the task will be a long one.

It is for this reason that a realistic outlook would involve assuming that, in view of the magnitude of the problems, the subregion's economies are likely to stagnate for a fairly long period of time, in differing degrees and with ups and downs from one year to the next, but nonetheless within an overall framework of quasi-stagnation. This in no way means that countries are condemned to wallow in a permanent slump, but it does mean that it will be vital to carry out a vigorous policy of reactivation and development allowing the Central American subregion to reorganize its considerable natural and human resources in order to lay the foundations for sustained development.

\section{IV}

\section{Bases for a policy of reactivation and development}

It would be just as absurd to assert that there is no way out of the crisis - there is a way out of any problem facing human activity- as to imagine that there are ready-made or copybook solutions at hand for reactivating the economies of Central America and setting them on the path towards generalized prosperity. Between that vision which predicts a permanent depression and the other which is Utopian, there is a whole range of intermediate situations which could gradually pave the way for a policy of development. The following pages provide an examination of some critical areas for laying down those foundations, in the hope of stimulating debate on the response to the many sided and complex challenge facing Central Americans.

\section{Observations on the aims of the reactivation and development policy}

It is the Secretariat's view that one of the first issues with the Central American governments ought to tackle is the set of aims to be pursued in a reactivation and development policy. As is well known, the conventional aims of development involve growth, improvement of income distribution, reduction of the economies' vulnerability to external factors, and promotion of changes not only in the economic, but also in the social and political spheres. It is thus sought to establish societies which are more pluralistic, participative and democratic.

It is vital to establish an order of priority among these aims, not only because it is doubtful whether they can be pursued simultaneously - even during periods of prosperity, and even more so during times of austerity- but also because espousal of one of these objectives in preference to the others will determine the nature of the set of economic policies to be adopted. For example, if a particular government resolves to give priority to social justice, it could decide to favour particular instruments of economic policy (agrarian reform, greater expenditure on social services, periodic wage adjustments) which could have the counterpart effect of discouraginng private investment and thwarting the achievement of growth. In other words, regardless of the neoclassists' conclusion that the aims of distribution and growth are compatible (by 
means of the proverbial "overspill" of the fruits of growth), the experience of Central America, and indeed of Latin America as a whole, during the three postwar decades indicates that considerable trade-offs are involved between the various aims of development. There is very little empirical proof to support the idea that good things come in packets (Packenham, 1973, p. 123) or that it is possible to simultaneously grow, improve income distribution, acquire autonomy and advance towards more democratic societies (see Wolfe, 1984).

Naturally, this does not mean that the oftmentioned aims are in no way laudable and worth pursuing. Nor is it necessary to pursue only one or a few of them at the expense of the others. However, it is necessary to clarify the relative importance of each of them - and their mutual relationship - in the light of the programme of reactivation or development which the circumstances require. Thus, under present circumstances in Central America, some governments might single out the target of social justice, even if this involved sacrificing growth targets; others might seek to maximize growth, possibly in an attempt to recover part of the ground lost in recent years and to meet the need to create jobs for a rapidly-growing economically active population. Still others might prefer to promote social harmony, together with pluralistic and democratic institutions.

All these objectives are worthy in themselves. Nevertheless, the diagnosis made in the first two sections of this article would seem to suggest - at least as a basis for discussion in governmental forums in each country as well as in intergovernmental ones at the subregional level- that under present circumstances, what the Central American countries require above all, both in the economic and social spheres, is a broadening of the extremely narrow leeway which is available at the present time for them to formulate economic policy and forge their own destiny; that is to say, reduction of their external vulnerability. ${ }^{9}$

\footnotetext{
"The following ideas are deeply influenced by the posthumously published work of Professor Dudley Seers (1983). The author makes frequent use of the terms margin of action almost as a synonym for acquiring autonomy or lowering external vulnerability.
}

In the economic field, the practical pursuit of this aim would, for example, involve the following: seeking relative self-sufficiency with regard to food supply, without neglecting considerations of efficiency; development by the subregion of its own technologies for those activities of greatest importance to the Central American economies; diversifying and expanding exports; encouraging patterns of consumption less dependent on the use of imported goods; adoption of less capital- and energy-intensive production patterns; and intensive use of labour, the region's most plentiful resource. There is not necessarily anything novel about these ideas, but they bear a new sense of urgency. Outside the purely economic field, this aim would be expressed by asserting the historical and cultural identity of Central Americans and consolidating the concept of the nation-State. ${ }^{10}$

These concepts need to be carefully defined. First and foremost, acquiring greater autonomy or reducing external vulnerability should by no means be equated with autarky. The small scale of the Central American economies, even taken as a whole, and their vocation as exporters leave no doubt that their behaviour will remain closely linked to the performance of the external sector. It will be necessary, however, to seek a new, dynamic, diversified and selective insertion within the international economy, and not merely an indiscriminate "opening-up" which instead of reducing vulnerability would probably tend to increase it. In other words, the aim of diversifying and expanding the export sector is not to further increase dependence on the vicissitudes of the international economy, but rather to obtain greater leeway for the external relations of the Central American countries.

Secondly, greater autonomy should not be pursued at the expense of the conventional aims of development, but rather an effort should be made to achieve those other aims through the central objective, while attempting to ensure

"'Seers ( 1983. p. 9\} states that this involves promoting the supposed interests of a group possessing cultural coherence, which displays at least a certain degree of ethnic and linguistic homogeneity, and which generally lives within a political unit, or nation-State (it may occasionally apply to a group of nationStates). 
that they provide mutual support for one another. If, in pursuing the central objective of increasing the leeway available for economic policy, an effort is also made to pursue growth, improve distribution and encourage greater participation in the societies, it is perfectly possible that not all these aims will be optimized -it has already been observed that even in the best possible circumstances this would be impossible-, but neither will they be left aside. Thus, attempting to achieve a relatively selfsufficient food supply would not only help to reduce external vulnerability, but would also contribute to growth and even to redistribution, since food production is largely in the hands of small and medium-sized farmers. Likewise, stressing the interdependence of the Central American economies is not merely a means of fulfilling the oft-mentioned central objective; it could also appeal to cultural and historical values which would facilitate the subsequent establishment of the foundations of more participative and pluralistic societies.

Moreover, seeking greater leeway at the national level is functionally linked to the sociopolitical aims of improving income distribution and progressing towards societies with greater participation and pluralism. Thus, since governments are not only unable to use public expenditure as a means of exerting pressure on the agents of production, but also face social demands which have intensified as a result of the global decline in income, they will have to seek the consensus needed to obtain increased economic autonomy by trying to gain the agreement of a variety of social groups and incorporating them into de decision-making process. Similarly, they will need to set up mechanisms for improving social justice, both with regard to sharing out the burden of the economic recession and distributing the benefits of reactivation. The ability to use consensus as a course of action varies from one political régime to the next, and depends on the institutional traditions and structure of each country, but in every case there is a real chance that the central aim of broadening the margin of action available for national policy and the secondary aims of seeking greater social justice, consensus and participation in the decision-making process will provide mutual support for each other.
There is a social and cultural aspect to the heightening of Central American identity, which overlaps into the economic and political sphere. It is indeed tempting to propose that Central American development should be not merely a mirror image of an international pattern which is probably alien to the region's traditional values (and to the resources at its disposal), but rather the reflection of its own considerable historical and cultural heritage. This could have an influence upon the patterns of production and consumption, once again as a more autonomous attempt to tackle the problems of development.

Finally, favouring the acquisition of autonomy in preference to other aims possesses the additional advantage, in the case of Central America, of being a target with which all the governments of the region, without exception, can wholeheartedly identify. In view of the increasing diversity of approaches being adopted in Central America on the one hand, and the clear need for a minimum platform of common objectives to facilitate the formulation of joint action as part of the effort to achieve intraregional co-operation, on the other, it is perfectly logical to pursue the common and ideologically neutral aim of expanding the margin of action.

To sum up, this objective is capable of mobilizing all the Central American governments around an "idée-force", around which other subsidiary elements of equal importance for the revival of the economies, such as economic dynamism, social justice, participation and democratization, could revolve.

\section{Features of the desired productive structure}

The first requisite of a policy for reactivation and development is a precise definition of sectoral and sub-sectoral priorities. In this respect, the countries of the region could adopt a pragmatic approach designed to make maximum use of the possibilities which the international market continues to offer, while simultaneously giving a determined impetus to efficient import substitution.

Central America possesses a range of resources on which to base economic 
reactivation and long-term development. Although the size of the resources has occasionally been exaggerated, there is no doubt that they are capable of satisfying the basic needs of the whole of the population of Central America and even providing a fairly comfortable standard of living for most of them. However, in order to make maximum use of them, major investments are required, together with a big effort of mobilization and organization.

Thus, preparation of the labour force to adjust it to the changing circumstances of the international economy involves a major effort of training at all levels. This would involve the educational system both in and out of school. Moreover, there is no reason why Central America should resign itself to exporting five or six commodities; in view of its resource endowment and its geographical location, notwithstanding the uncertain outlook on the international market, there are opportunities for expanding and diversifying sales of a range of agricultural products (including fruit, vegetables, meat, fibres, marine products and chemical inputs of vegetable origin, all capable of undergoing gradually increasing degrees of processing). In addition, exploitation of forestry resources represents considerable potential in a number of countries. In this respect, the specialized evolution of the manufacturing sector in the northern European countries during the present century could provide a number of worthwhile lessons, as could the progress achieved by a number of Asian economies in the export of manufactures involving a high labour input.

It is within these branches of activity, that the stimuli for future growth, which could be classified into four major categories, are to be found. First of all, it is necessary to consolidate the know-how which the region already possesses: with regard to exports, we must strengthen production of traditiorial crops; with regard to domestic consumption, that of basic foodstuffs. This will require an increase in productivity and efficiency, the achievement of a better agricultural and ecological balance between the various crops and production areas and, in the case of a number of products, an increase in supply if national economic autonomy is to be increased.
Nevertheless, it would be difficult for the subregion to achieve a process of sustained expansion upon the basis of past practice. Traditional export products are subject to wellknown restrictions in world demand originating in the features of the markets for most of them (the one exception might be meat); on the supply side, the easily expandable agricultural frontier has been near its limits since the end of the 1960s. This does not mean that a ceiling has been reached in the production levels of coffee, cotton, sugar cane and bananas, but it does mean that any further expansion of this frontier will involve increasing marginal costs in the future.

Secondly, it would be desirable to encourage greater selective integration (both backwards and forwards) of traditional products, so as to increase Central America's share of their added value. In spite of the protectionist measures adopted in the developed economies, which, for example, restrict the access of plain textiles and clothing manufactured in Central America to their markets, there is still room for increasing the degree of processing of a number of commodities produced in the region with a reasonable degree of efficiency. At the same time, Central American entrepreneurs will need to take a more active role in marketing their products, even to the point of establishing firms in those developed countries whose markets they wish to penetrate. There is potential in this sphere for associating private Central American capital with capital in the industrialized economies in an effort to broaden markets and develop more complex productive processes.

Thirdly, it is possible to selectively encourage new export lines, particularly on the basis of exploitation of the region's natural resources. Products which show promise and which, in addition, are capable of being integrated into secondary activities include vegetables, citrus fruits, tropical fruit, hard fibres, pharmaceutical products, forestry and wood products, and seafood, including shrimp farming. In addition, subcontracting is a potential source of productive work as well as of foreign exchange.

Fourthly, the potential for expanding and diversifying the manufacturing sector is far from exhausted. On the contrary, as a result of the abnormal way in which the Central American 
Common Market has been operating in recent years, there is a backlog of projects whose viability depends on an improved climate for intra-regional co-operation, not only in order to supply demand on the subregional market, but also to penetrate outside markets, including of course the other Latin American countries. In this respect, mention should be made of the fact that Central America has already achieved a certain amount of success in transforming integration into a platform for extra-regional exports of manufactured goods (ECLAC, 1983b). In other words, today as in the past, import substitution under reasonable conditions of efficiency represents a means of enlarging the margin of action available to economic policy as well as of diversifying and increasing production.

Finally, the region possesses potential for expanding its tertiary activities, including transport, tourism and financial services. The last of these may be of particular importance in restoring former levels of saving and investment, which will need to be tapped by more flexible and innovative instruments than those which exist at present.

To sum up, and by way of an initial conclusion, it is possible to assert that the region possesses a human and natural resource base capable of permitting the sustained expansion of production. The central task will be to create the necessary institutions and forms of organization to take full advantage of this potential.

\section{3- Requirements of a policy of réactivation and development}

In the present climate of uncertainty and of sharp turnarounds in the international economy, and under the heavy burden of the accumulated lags described above, any policy of reactivation and development involves a set of minimum requirements which include pragmatism, selectiveness, austerity, efficiency and the search for means of satisfying the minimum requirements of those groups which constitute the majority of the population.

\section{a) Pragmatism}

One of the main problems which arises when formulating an economic policy is the uncertainty which largely stems from factors outside the control of the governments of the region. Reference has already been made to the doubts which have arisen as to the future evolution of the international economy, the changes which the industrialized economies must face, or the results of the policies being implemented in some of the main industrialized countries. It is not yet known what influence these factors could have in the countries of Central America, nor is there any clear perception of what the final outcome of the grave political and social tensions present in some countries of the subregion will be.

The foregoing means that the economic policy of the Central American countries must be designed and applied with flexibility and realism so that it can be progressively adapted and adjusted to changing, unpredictable and basically unprecedented circumstances. This pragmatism will take various forms. First of all, flexibility and effective responses imply some degree of break with the past, because traditionally policies have tended to react passively or with considerable delay to the vicissitudes of the international economy. Today, in view of the risk that what we are facing is not so much a recessive cycle as a structural change in the world economy, it will be necessary to build a response capacity which will make it possible to take advantage of even the slightest opportunities and reduce as far as possible the factors limiting the development of the countries of the subregion: aspects which have particularly important repercussions as regards the role corresponding to the State.

Secondly, notwithstanding the increasing conceptual polarization which prevails as regards the way in which economic development should be tackled, the pragmatic approach must, by definition, be anti-doctrinaire. This is not the moment to be trying out particular economic doctrines, as recent experience in Latin America has shown so eloquently. It is far more important to break with historical stereotypes: those governments which desire to give a leading role to the State cannot afford to refuse to provide incentives and their full support for private investment, nor should those which place their confidence in the market as the ideal resource allocation mechanism be scared of 
assigning a more active role to the State. In other words, what present circumstances require is a search for the happy medium between extreme propositions for economic policy management (for example, between "liberalization" strategies and "inward-looking" strategies; between "distribution" and "growth"; between governmental and private action; between the application of policies in the financial field and in the real economy), as well as an innovative mixture of these. For example, there is no reason why a government should not return inefficient public enterprises to the private sector while simultaneously increasing the tax burden so as to tap greater funds in order to provide the population with basic services, or introduce agrarian reform designed to create a larger number of small agricultural entrepreneurs, while simultaneously encouraging saving and private investment by granting tax incentives.

Thirdly, in view of the changing condition in the international economy, economic policies will need to take these new circumstances into account. It will be necessary to become reconciled to the fact that the era of fixed exchange rates and stable interest rates has given way to quite different systems, making it necessary for the application of those policies in Central America to be flexible and consistent with the aims pursued.

Fourthly, and precisely as one means of adjusting the application of economic policy to changing circumstances, it will be necessary to cease insisting on universal approaches in favour of more pragmatic criteria of limited scope, designed to solve critical problems associated with reactivation and development, rather than to be a general panacea. This in no way means abandoning overall guidelines for efforts to achieve the aforementioned objectives, but it does involve placing greater reliance than in the past on a selective method of trial and error, as a means of advancing towards reactivation and adjusting economic policy as circumstances require.

\section{b) Selectiveness}

It will not be sufficient for the policy of reactivation and development to be applied pragmatically; it will also need to be selective.
This concept too is many-sided. For example, the disarray in the international economy means that it is just as risky to direct the whole of economic policy towards encouraging dynamic insertion into world trade as it would be to adopt a policy which would make it impossible to take advantage of this trade. Economic policy should be sufficiently flexible and selective to be able to adjust to changing circumstances on external and domestic markets. Thus, contrary to what is generally assumed, the greatest threat nowadays to the efficiency of Central American industry is not so much exaggeratedly high tariff protection as the high levels of idle capacity which exist as a result of the fall in overall demand in each country and the barriers to intra-regional trade. Consequently, export promotion measures should not be adopted at the expense of destroying the hard-earned achievements of recent decades, but rather by selective and gradual application, in order that those articles with greatest potential access to international markets receive special incentives, while existing industry and a number of new activities may develop within a framework of reasonable protection in order to substitute imports.

In the same line of ideas, economic policy in general, and public expenditure policy in particular, will need to be applied in a far more selective fashion than in the past, in keeping with the aims chosen. For example, it would be preferable to completely eliminate low-priority programmes from the national budgets rather than to cut all budget items by a fixed percentage. The same selectiveness could be applied to credit, fiscal and tariff policy.

Finally, given the prevailing lack of confidence among the main economic agents, it would be unwise to leave reactivation policies at the mercy of the evolution of the international economy and solely dependent on the interplay of market forces. Thus, for example, in view of the acute shortage of foreign exchange affecting all the subregion's economies, it would be quite inappropriate to simply rely upon the interplay of supply and demand for foreign exchange as a means of setting exchange parity, especially since repressed needs and speculative pressures tend to value "hard" currencies above the level they deserve. Similarly, it would be equally risky to rely solely on administrative controls and 
excessive centralization in the application of economic policy as a means of tackling maladjustments of external and of domestic origin.

\section{c) Austerity}

The widespread depression in Central America has been reflected in a number of restrictions associated with the need to reduce imports and ultimately levels of economic activity. The resulting austerity has by no means had an equal impact on the different strata of the population, however. The shortage of foreign exchange, the need to mobilize domestic saving in view of the restrictions on external financing, and the need to satisfy the most basic needs of the population make it necessary to ensure much more selective and careful use of the resources generated by exports and, in general, to follow a pattern of expenditure which closely respects priorities. In short, the new economic circumstances mean that the structures of expenditure and saving must also be adapted to them, and this should be reflected in austerity consumption patterns in both the private and public sectors.

This austerity should have a dual aim: to save foreign exchange through the reduction of consumption of non-essential goods and services which are either imported or have a high imported content, and to increase the coefficient of saving. As regards the first of these aspects, the countries of the region must use the foreign exchange they manage to obtain from their exports with the greatest care and strictest selectivity, which will involve, among other features, realistic exchange rates. As regards consumption, governments will need to discourage the consumption of non-essential goods and services of external origin, while they should take maximum advantage of national and subregional potential for supplying demand. Setting a high value on thrift rather than extravagance could be reflected in a different life style from that of the past, particularly among the middle- and high-income groups of Central American societies. There is of course no question of further lowering the living standards of the majority of the population who already live on the threshold of poverty. On the contrary, the reactivation policy also involves an effort at redistribution which among other features, should provide greater support for the satisfaction of the population's basic needs.

As regards investment, everything points to the desirability of looking once again at the possibilities of using more labour-intensive technlogies, not only because of the pressing need to create jobs, but also because of the need to reduce the imported component in new fixed capital.

Improving the selective utilization of the foreign exchange generated by exports means that the governments of the subregion must do their utmost to rationalize public expenditure and reorient it towards truly essential activities. The foregoing assumes particular importance because, on the one hand, the persistence of the international crisis and other factors of a domestic nature foreshadow the intensification of social pressures on governments and, on the other hand, the markedly open nature of the Central American economies imposes strict limits on the deficit financing of public expenditure because of its inflationary impact and its repercussions on the balance of payments. In this respect, it will be necessary to suppress luxury or non-essential expenditure and to seek to advance in the political detente of the region, so as to be able to transfer part of the resources now devoted to military purposes to the promotion of development.

Furthermore, public expenditure itself could help to reduce the external imbalance if, in selecting investments, preference is given to projects which require a high proportion of national or subregional imports. At all events, the public sector will have to increase its procurement of revenue in line with its expenditure, in order to prevent financial deficits from contributing to inflationary demand for imported goods.

\section{d) iifficicncy}

Another basic requirement of a reactivation policy is that it should defend growth based on increased efficiency and productivity. In the present circumstances, improving efficiency is absolutely essential, both from the macro and micro economic point of view, in order to 
increase the multiplier effects of savings and investments, to substitute imports on reasonably competitive terms, or to maintain and expand exports to international markets. It is the duty of the State to improve the efficiency of those services which it provides and to encourage the improvement of the productivity of enterprises through fiscal and credit measures.

A significant increase in efficiency and employment in the subregion can be achieved without having to resort to imports of capital goods, by making full use of the existing installed capacity. There is considerable idle capacity, above all in almost all branches of the manufacturing sector. There is also ample room for considerably increasing the productivity per hectare in the case of most agricultural products, even those where the countries have had the greatest success with their exports.

\section{e) Reducing poverty}

If it did not prove possible to bring about any significant reduction in extreme poverty even during the thirty years of dynamic expansion of the Central American economies (although broad sections of the population were integrated into modern economic activity during that time) it is inevitable that the situation should grow worse as the economic crisis persists, since there is a direct interrelation between levels of employment and marginality. In recent years, open unemployment and underemployment have increased, and unless some way of avoiding this is found, this tendency will be aggravated in the future, in view of the rapid rate of growth of the economically active population.

Unless the State takes clear measures in favour of the masses, the depressive effects of the crisis - and of the austerity policies accompanying it- will tend to have a disproportionately severe impact on these groups, which are the least well organized to defend themselves, and among other consequences, this will bring about a widening of the gulf between the governing and the governed.

The spread of absolute poverty is unacceptable from any point of view. However, a policy aimed at satisfying the basic needs of the masses is hard to implement even in times of rapid economic expansion, and still more difficult to achieve at times of severe restrictions, including those affecting public finances. At all events, the elimination of poverty is an essential part of the development approach which is called for. Without it, all efforts to overcome the crisis would be meaningless, since the spread of social discontent could make social tensions unmanageable and make it impossible to retain savings and thereby revive the process of investment and development.

It is necessary to find some way of satisfying the basic needs of the populations which involves a relatively low imported component, in order to keep within the foreign exchange restrictions. At all events, and quite apart from considerations of equity, the political crisis in many countries of Central America has reached the point at which it is absolutely indispensable to restore a minimum of peaceful understanding among the population. If this is not done, then the social instability will inevitably be transformed into economic instability by paralyzing, for example, the process of capital formation and leading to a kind of Statedominated expenditure which would be of little help in expanding productive activities.

\section{The role of intra-regional co-operation}

Beyond any doubt, intra-regional co-operation offers the best possibility of loosening the constraints imposed by the external sector on the Central American economies, in line with the need to establish bases for reactivation and development set forth in this article. Today, more than ever, it is necessary to press on with the programme which was begun in Central America nearly thirty years ago and which has borne such valuable fruits and experience. It is necessary to do so not only in order to take advantage of the more dynamic impulses which could be expected from domestic demand (understood on a subregional basis) but also in order to face up jointly to certain specific features of the subregion's relations with the rest of the world. This aspect has been dealt with on a number of occasions in ECLAC documents, but it acquires fresh interest in the present circumstances. 
The aim would be, through intra-Central American co-operation, to increase the scanty room for action available to each of the individual countries of the subregion, in order to thus lessen the effects of the depression of the external sector. In the short term, the only effective way of expanding local demand seems to be that connected with co-operative efforts at the subregional level. There is nothing new about such a procedure, since as long ago as in the 1950s it was successfully put into practice in order to overcome the same obstacle, namely, the bottleneck to growth constituted by international demand. Now, however, it would be adopted in a different situation. If it were possible to increase intra-regional trade to the maximum, this would make an effective contribution to economic reactivation by making maximum use of installed capacity, reducing the influence of the adverse effects of external sector phenomena, increasing efficiency - both for import substitution and for improving competitiveness on international markets- and even taking joint advantage of the opportunities which the international market may continue to offer.

In recent years all of this has been hindered by the barriers standing in the way of intraregional trade. It would be unrealistic to defend unrestricted free trade which did not take account of the greater or lesser importance of the goods being traded, but it would be desirable at all events to keep restrictions to the minimum and even to adopt mechanisms to give preference to reciprocal trade over similar trade flows with third countries. In this way alone could optimum use be made of the installed capacity of the subregion, while even perhaps also promoting some new activities based on subregional demand. For this purpose, the countries would need to adopt new procedures for financing the intra-Central American trade debit balances, to do away with certain restrictions at present resulting from the exchange controls adopted, and, in general terms, to give essentially the same treatment $\mathrm{Co}$ products originating from any other Central American country as to those produced domestically. There is no shortage of concrete ideas in the subregion for bringing this about.
Furthermore, as already noted, regional cooperation is the best way of improving the use made of the opportunities offered by the international economy, both in order to increase exports —on the basis, for example, of common marketing systems - and in order to obtain additional external financing for projects and initiatives which are of interest to all. The strengthening of the Central American Bank for Economic Integration and of the machinery available through the Central American Monetary Council are examples of some measures which would give real force to this latter idea. It should be remembered that lack of intra-regional co-ordínation in such a vital area as external financing not only has a high opportunity cost -if the possibilities for joint mobilization of a flow of resources which could not be obtained through individual negotiations are lost - but also represents a risk for the survival of intra-Central American co-operation. It has been noted that various actors on the international scene seem to be interested in providing co-operation to the Central American countries on a selective basis, with the exclusion of one or more countries from their programmes. In this respect, external cooperation would tend to separate the Central American countries rather than uniting them.

Making intra-regional co-operation one of the pillars of reactivation and development will call, in the first instance, for the simple preservation of the degree of economic interdependence already reached, while subsequently promoting joint action to correct or relieve common problems. There would be no question, of course, of seeking to promote instant integration of the economies of the region or co-operation in every single one of their activities. What would be sought for would be rather to make integration a useful instrument for tackling the reactivation of each country. Thus, for example, tariff policy — which has traditionally been the subject of joint action - could play a key role in the application of a more selective and flexible system, simultaneously ensuring both protection of existing industrial plants and the promotion of exports. In addition, although there is no question of establishing regional commitments 
which restrict each country's possibility to formulate its own exchange policies, it is clear that the existence of the common market will call for a minimum of co-ordination in this sphere, which will further facilitate the adoption of decisions to meet the needs of reactivation.

The schedule of integration activities over the next two years will need to incorporate measures which, while preserving the economic interdependence already achieved between the countries of the subregion, will facilitate the adoption of policies linked to the programme under discussion. Noteworthy among these issues are: i) the continuation and perhaps intensification of joint action vis-a-vis the international financial community in order to mobilize external funds so as to provide foreign exchange liquidity for those regional mechanisms which ensure the fluidity of intraregional trade; $\ddot{u})$ increasing the flow of external funds for industrial reactivaton; iii) transforming the Central American common tariff into an instrument of the reactivation and development policy, taking advantage of the recent signing of the agreement on the Central American Tariff and Customs Régime; ${ }^{11}$ iv) stimulating joint action to improve the access of Central American products to the markets of third countries; v) drawing up partial agreements, in coordination with other countries in Latin America, so as to harmonize the steps towards Central American integration with the need to expand the geographical area of this integration; vi) coming to grips with the specific problem of those countries which do not reap the full benefits of intra-ragional trade, by devising means for allowing Nicaragua's exports to the rest of the region to increase as well as for the gradual and progressive incorporation of Honduras into the multilateral integration commitments; vü) carrying out joint projects of multinational interest, such as the interconnection of electricity systems and cooperation in the exploitation of marine resources and, viii) strengthening the Central

"Signed in Guatemala on 14 December 1984 by the governments of Costa Rica and El Salvador, and on 27 December 1984 by the governments of Guatemala and Nicaragua.
American integration institutions so that they can help to carry out the activities in question.

\section{The political expression of development and the role of the State}

Although this article has focused on the role of economic policy —and by implication, on that of economists - in reactivation and development, it is clear that this is not the exclusive preserve, or even the main one, of economists. The transformations inherent in any development process affect all areas of national life (and all of the social science disciplines) and it is hardly possible to design programmes of reactivation and development without incorporating considerations of a social and political nature. Thus, should it not prove possible to overcome the persistent tension in a number of Central American countries, it would be pointless to consider reactivating their economies. In other words, it is necessary to adopt a multidisciplinary approach to development so that economics can incorporate such issues as participation, political interaction, the role of the various economic agents and democratization.

This does not mean that the multidisciplinary approach must be adopted in all activities connected with the development effort. The formulation of economic policy proposals remains principally the task of economists, the study of political interaction that of political scientists, and research into social stratification that of sociologists. Nevertheless, there will be numerous areas of contact and overlapping between economic, political and social factors, and a reactivation and development programme will consequently need to tackle at least some of the non-economic factors present in the region, as already indicated in this article.

This is no place to develop this issue in depth. Nevertheless, it is necessary to make a few remarks concerning the role which the State could play, merely in order to provide an illustration of the complex interrelations between economic and non-economic factors in this great task facing the Central American governments and peoples. Why should particular attention be devoted to the role of the 
State? Firstly, because this article is intended essentially for the region's governments, and it would be incomplete if it failed to examine the role incumbent upon them in reactivation and development. Secondly, the issue is highly controversial -sometimes with marked ideological overtones - and deserves both broad debate and deeper subsequent research. Finally, irrespective of the ideological and conceptual framework surrounding the issue, each of the generic functions carried out by any State - preserving order, defending sovereignty and ensuring the well-being of the population- is reflected in the central preoccupations underlying this article, such as how to overcome the social and political tension in the region, to reduce the marked influence exerted by phenomena of external origin on all aspects of national activity, and to reactivate the economies. The issue is thus clearly of considerable importance.

Nevertheless, the role played by the State may vary considerably in detail from one country to the next, or within a single country at different periods of time, depending upon the existing institutional and political organizaton, historical and cultural tradition, the result of political interaction and a number of diverse circumstances.

This question also involves ethical and philosophical considerations (for example, if it is accepted that the State plays a leading role, is it entitled to use any means, including force, to influence events? What bounds are to be set to the procedures which the State may adopt to achieve this end?). These problems are ali clearly evident in present day Central America, in view of the heterogeneity of the situations existing in the region.

In a number of countries the power of the State is perceived as the result of permanent tensions between different agents within society, with its bounds being set by other centres of power and by the rule of law. In other countries, there is a tendency to endow the State with a hegemonic (but not necessarily absolute) role, in certain cases as the representative of particular sectors of society. It is consequently impossible to define a single formula, applicable to each and every one of the countries, regarding the precise role which the State should assume in the process of reactivation and development, that is to say, with regard to its generic role as guardian of the population's well-being. Indeed, the very same criteria applicable to reactivation policy, as referred to earlier (pragmatism, selectiveness, efficiency and austerity), are relevant to defining both this role and the relations of the State with the other economic agents in society. In addition to these criteria, it is necessary to take full account of the heterogeneity of situations and to ensure that there is capacity to adjust the role of the State to changing circumstances.

Thirty years of Central American experience would seem to indicate that there is no universal rule to permit an ex ante definition of the degree of State intervention desirable for maximizing the population's well-being. It has to be acknowledged that the performance of the State during this period has not always been satisfactory, as is illustrated by the cases of a number of public enterprises or official industrial development institutions. The fact that a number of these enterprises have been victims of bureaucratization, sinecures, and even occasionally corruption and ineptitude in their administration, should not automatically lead to the conclusion that they are perforce inefficient. Nevertheless, it has to be acknowledged that the fashionable trend during these thirty postwar years towards the systematic expansion of the scope and depth of State action has not always proved intrinsically desirable, and in general the State's activities should have to meet the same requirements of efficiency, honesty and flexibility as those of other economic agents. On the other hand, it would be equally wrong to conclude from this performance that the State must withdraw from playing a major role in development, and instead rely on the market as the sole arbitrator of this process.

It would be more consistent with Central American circumstances to accept that the degree of State intervention in the economy or the influence allowed market forces should depend on the prevailing conditions in each country. Basically, apart from the family and the home, the two most important organizational institutions in the world are the market and the State (Lindblom, 1977, p. II). For this reason, once the necessary presence of both these 
"organizational institutions" in any political system —including socialist economies- has been acknowledged, the greatest distinction between one government and the next lies in the degree to which the market replaces the government or to which the government replaces the market (Lindblom, 1977, p. IX).

One way of perceiving the role played by the State, then, would involve observing the tense and dynamic relationship between the two organizational institutions - the market and the State- described above: tense because they are constantly face to face, each sounding out the limits of the other; dynamic because changing circumstances lead to modifications in the relative weight of each, as well as to changes in their interrelationships. For this reason, during periods of intense change such as those which Latin America is experiencing at the present time it is unavoidable that both the role of the State and that of the market will also undergo changes. Both interact with one another in a creative state of tension.

Once this approach has been accepted, it is neither possible nor necessary to put forward a universal rule for the role which the State ought to play in a region containing situations so diverse as those in Central America. There would be no point in abstractly proclaiming either a hegemonic role for the State or the universal virtue of the market. The relative share of each of them in the evolution of events will depend on the dynamics of the development process itself as well as on the prevailing circumstances in each country.

However, if the features of the present situation are scrutinized it is apparent that the public sector possesses room for action which it should use not only to soften the harmful impact of the crisis, but also to orientate the effects of the crisis in a constructive direction. For example, the shortage of foreign exchange requires the establishment of an order of priority for the different importing sectors and means, moreover, that income from exports should be specifically devoted to essential imports. In addition, present circumstances require a major effort directed at exports. It seems logical that the central banks and the offices responsible for external trade should assume responsibility for these functions. At ail events, the obligation to rationalize the use of foreign exchange requires greater State intervention than is required under normal circumstances of external relations.

Moreover, the shortage of foreign exchange leads to conflicts of interest and, consequently, pressures from the various groups of importers and exporters. The clashes which invariably arise as a result of these situations can only be solved through the arbitration of a higher authority. In this respect, regardless of the combination of exchange, credit or fiscal formulae adopted in order to face the crisis, the shortage of resources automatically intensifies the struggle between the interest groups and thereby opens up -as a result of the fragmentation of demands- a broader area for public-sector intervention.

Another qualitative change in the role played by the public sector springs from its lesseer dependence on international trade as a direct source of tax income. The decisive role which exports have played in the past has led to taxes on external trade being of considerable weight in public-sector income, but this situation will change as the external depression restricts the possibilities for exports and, as a counterpart, those for imports. Consequently, financial problems will arise until new domestic sources of taxation can be found, but, simultaneously, the State will become less vulnerable to specific pressure groups.

These considerations all illustrate the way in which the prevailing situation affects the role of the State, regardless of the conceptual and ideological framework of each Central American society. Naturally the exact nature and scope of its responsibilities will vary from one country to the next as circumstances dictate in each country, as a result of the interaction between the State and the other economic agents. In this respect, the execution of its activities by the State in the manner described would be the natural counterpart of the pragmatic approach put forward earlier with respect to the management of economic policy, with less emphasis on global and universal frameworks, but instead selective methods involving a process of trial and error in order to achieve given development aims. 


\section{Bibliography}

CELADE (Latin American Demographic Centre) (1981): Boletín demográfico, XIV, No. 28.

CLADES (Centre for Latin American Development Studies) (1984): La ventaja comparativa de corto plazo en la producción manufacturera de Guatemala. Boston: Boston University, January, mimeographed.

BCLAC (Economic Commission for Latin America and the Caribbean) (1983a): The crisis in Central America: its origin, scope and consequences (E/CEPAL/G. 1261), 22 September.

(1983b): Centroamérica: la exportación de productos industriales y las politicas de promoción en el contexto de la integración económica (E/CEP AL/MEX/ 1983/L. 10), February.

(1985): Centroamérica: el financiamiento externo en la evolución económica, 1950-1983 (LC/MEX/L.2), 4 March.

Federal Reserve System (1979): Federal Reserve bulletin, Vol. 65 , No. 12. Washington, D.C, December, table A60.

(1984): Federal Reserve Bulletin, Vol.70, No. 7. Washington, D.C, July, table A56.

Gilder, G. (1981): Wealth and poverty. New York: Simon and Schuster.

Hirschman, A.O. (1981): The rise and decline of development economics. Essays in trespassing: economics to politics and beyond. Cambridge: Cambridge University Press.

Hoffmann, S. (1968): Gulliver's troubles or the setting of American foreign policy. New York, McGraw-Hill Book Company [Published by the Council on Foreign Relations]).
Huntington, S. (1981): American politics: the promise of disharmony. Cambridge, Mass.: The Belknap Press of Harvard University Press.

Kristol, I. (1978): Two cheers for capitalism. New York: Basic Books.

Lindbolm, C. ( 1977): Politics and markets. New York: Basic Books. Murrey, C. (1984): Losing ground. New York: Basic Books.

Nau, H. (1984-1985): Where Reaganomics works. Foreign Policy, No. 57.

Packenham, R. (1973): Liberal America and the third world. Princeton: Princeton University Press. [The quotation is ascribed to Samuel P. Huntington, Political order in changing societies. New Haven, Yale University Press, 1968, pp. 5-7.]

Perkins, D. (1962): The American approach to foreign policy. Cambridge, Mass.: Harvard University Press. Revised edition.

Podhoretz, N. (1980): The present danger. New York: Simon and Schuster.

Seers, D. (1983): The political economy of nationalism. Oxford: Oxford University Press.

Treasury Department (1980): Treasury Bulletin. Washington, D.C, October, table CM-II1-1.

(1984): Treasury Bulletin. Washington, D.C, fourth quarter, Table CM-IH-2.

Wolfe, M. (1984): Towards democratic alternatives (E/CEPAL/R.351) 